\title{
Review \\ A Review on the Antimicrobial Activity of Schiff Bases: Data Collection and Recent Studies
}

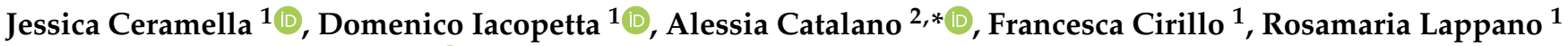 \\ and Maria Stefania Sinicropi ${ }^{1}$ (D)
}

1 Department of Pharmacy, Health and Nutritional Sciences, University of Calabria, 87036 Arcavacata di Rende, Italy; jessica.ceramella@unical.it (J.C.); domenico.iacopetta@unical.it (D.I.); francesca.cirillo@unical.it (F.C.); rosamaria.lappano@unical.it (R.L.); s.sinicropi@unical.it (M.S.S.)

2 Department of Pharmacy-Drug Sciences, University of Bari “Aldo Moro”, 70126 Bari, Italy

* Correspondence: alessia.catalano@uniba.it; Tel.: +39-0805442746

check for updates

Citation: Ceramella, J.; Iacopetta, D.; Catalano, A.; Cirillo, F.; Lappano, R.; Sinicropi, M.S. A Review on the Antimicrobial Activity of Schiff Bases: Data Collection and Recent Studies. Antibiotics 2022, 11, 191. https:// doi.org/10.3390/antibiotics11020191

Academic Editor: Bernhard Witulski

Received: 13 January 2022

Accepted: 31 January 2022

Published: 1 February 2022

Publisher's Note: MDPI stays neutral with regard to jurisdictional claims in published maps and institutional affiliations.

Copyright: (c) 2022 by the authors. Licensee MDPI, Basel, Switzerland. This article is an open access article distributed under the terms and conditions of the Creative Commons Attribution (CC BY) license (https:// creativecommons.org/licenses/by/ $4.0 /)$.

\begin{abstract}
Schiff bases (SBs) have extensive applications in different fields such as analytical, inorganic and organic chemistry. They are used as dyes, catalysts, polymer stabilizers, luminescence chemosensors, catalyzers in the fixation of $\mathrm{CO}_{2}$ biolubricant additives and have been suggested for solar energy applications as well. Further, a wide range of pharmacological and biological applications, such as antimalarial, antiproliferative, analgesic, anti-inflammatory, antiviral, antipyretic, antibacterial and antifungal uses, emphasize the need for SB synthesis. Several SBs conjugated with chitosan have been studied in order to enhance the antibacterial activity of chitosan. Moreover, the use of the nanoparticles of SBs may improve their antimicrobial effects. Herein, we provide an analytical overview of the antibacterial and antifungal properties of SBs and chitosan-based SBs as well as SBs-functionalized nanoparticles. The most relevant and recent literature was reviewed for this purpose.
\end{abstract}

Keywords: Schiff bases; antibacterials; imine; nanoparticles; chitosan; antimicrobials; chitosan-based Schiff bases

\section{Introduction}

Schiff bases (SBs) are organic compounds characterized by an imine or azomethine group $(>\mathrm{C}=\mathrm{N}-$ ) that are widely used as pigments and dyes, catalysts, polymer stabilizers [1], luminescence chemosensors [2] and intermediates in organic synthesis [3]. SBs can also be used as corrosion inhibitors for different metal-electrolyte systems, since they adsorb and form a corrosion-mitigating surface film through their electron-rich centers, including the imine moiety. In fact, this moiety can offer strong bonding with metallic ions because of its $\pi$-acceptor properties [4-6]. Moreover, several studies addressed the tribological activities of SBs and their role as biolubricant additives [7-10]. Additionally, the use of SBs as catalysts in fixation of $\mathrm{CO}_{2}$ to mitigate its accumulation in the atmosphere has been widely described [11]. SBs have also been studied in the carbohydrate research field in relation to Amadori products [12] and in material chemistry for applications in photoactive solar energy [13,14] and vitrimers [15]. Moreover, chemical reactions involving SBs may be found in sensors used to analyze illicit drugs and determine analytes in seized samples [16]. The exceptional popularity of SBs in organic chemistry can be attributed to their simple synthesis techniques, which use cheap materials. In fact, different synthetic routes continue to be described in the literature [17-19]. In biological chemistry, SBs have demonstrated a broad range of biological activities [20], including antimalarial, antiproliferative [21], analgesic, anti-inflammatory [22], antiviral, antipyretic, antifungal [23] and antibacterial [24] properties (Figure 1). The imine or azomethine group $(>C=N-$ ) seems to be critical for their biological activities. 


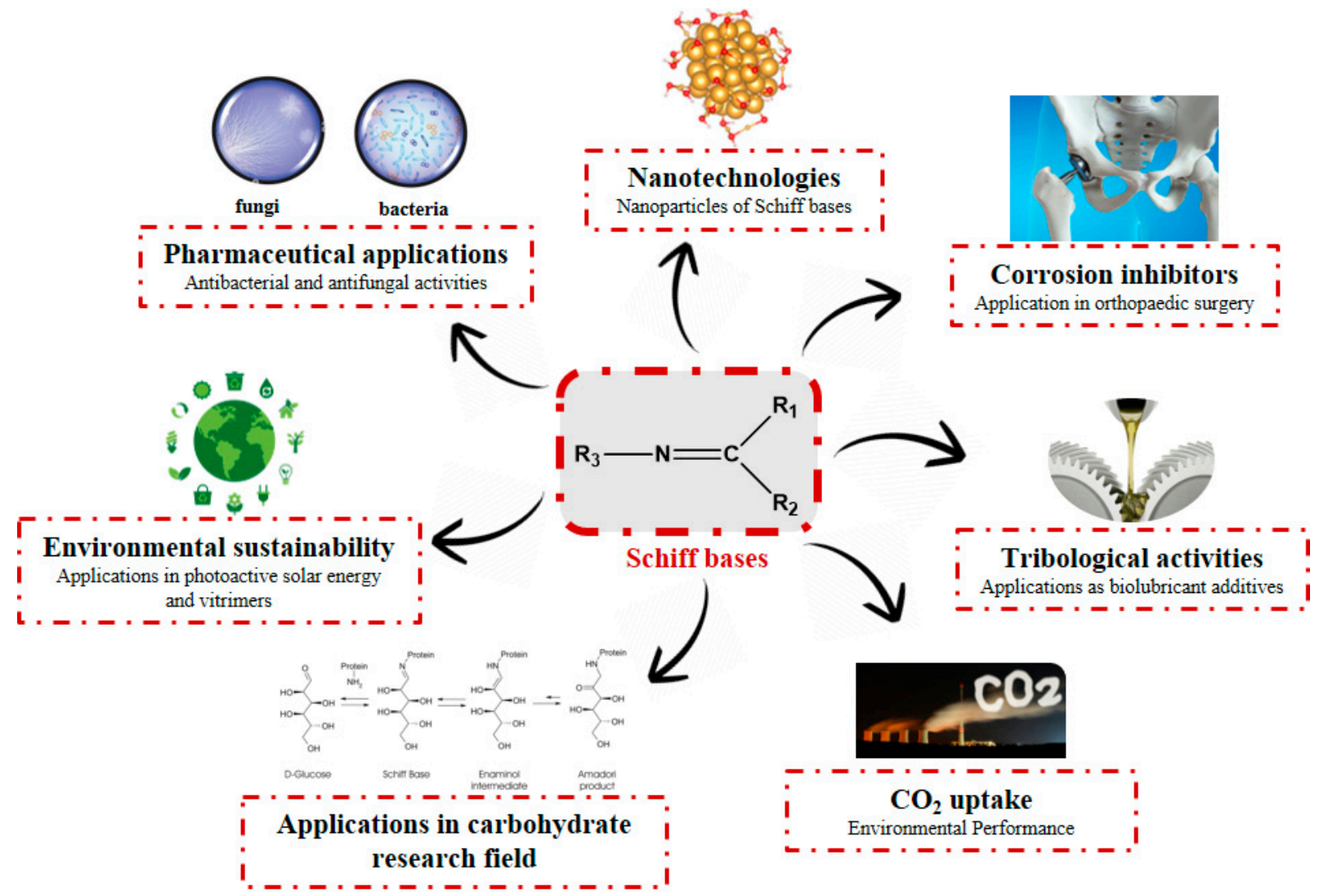

Figure 1. Main properties and uses of Schiff bases.

Recently, evidence on anticancer effects elicited by SBs has been provided [25,26]. It is worth noting that, in most cases, higher activity has been reported for SBs-metals complexes, rather than SBs alone $[27,28]$. Indeed, the presence of unpaired electrons on the nitrogen atom of the azomethine moiety gives strong chelating ability to SBs. SBs are now considered interesting ligands for coordination chemistry, thanks to their chelating ability along with, the convenience of separation and flexibility on the $\mathrm{C}=\mathrm{N}$ group [29]. In recent years, the phenomenon of antibiotic resistance in hospitals, communities and environment has increasingly grown. It is known that the overuse of antibiotics has led to an increase in bacterial resistance [30] and, in turn, to decreasing efficiency of the rare available antibiotics [31,32]. It is noteworthy that, also in this case, the complexation of SBs with metals generally leads to enhanced antibacterial and antifungal effects in comparison with free SBs [33-35]. Recently, a novel and green cellulose-based antibacterial complex of an SB with copper was fabricated. Its antibacterial activity against Escherichia coli and Staphylococcus aureus increased by $472 \%$ and $823 \%$, respectively, in comparison to the SB ligand [36]. However, SBs complexes are not totally devoid of disadvantages. For instance, when using SBs as homogeneous catalysts there can be reduction in the activation level in the process, demanding the recovery and recycling of catalyst and metal contaminations in products [37]. Moreover, the keto-enolic tautomeric isomerism that may occur at the double bond $\mathrm{C}=\mathrm{N}$, in the presence of ortho-hydroxy groups, may lead to different activities for the two tautomers [38]. Considerable interest has also been recently devoted to chitosan-based Schiff bases (CBSs) for their application in various fields such as biology, catalysis, sensors and water treatment [39]. Chitosan is a polysaccharide of natural origin, obtained from marine crustaceans, mollusks, insects and fungi. Of note, chitosan has shown antitumor, antiulcer, immunostimulatory, antidiabetic, antioxidant and antibacterial activities [40]. Recently, chitosan and its derivatives have also received attention as adsorbents for heavy metal ions and their removal from wastewater [41-43]. Nanoparticles represent an excellent platform for a broad range of biological and biomedical applications. Schiff 
base-functionalized nanoparticles have often been used for the determination of heavy metal ions [44]. Recently, the synthesis of core-shell $\left(\mathrm{Fe}_{3} \mathrm{O}_{4} @ \mathrm{SiO}_{2}\right)$ magnetic nanoparticles functionalized using an SB ligand for uranium extraction has also been reported [45]. Currently, nanoparticles may represent a promising approach for fighting antimicrobial resistance [46]. In this scenario, and given the need to identify new therapeutics in the antimicrobial field, this narrative review aims at highlighting the recent studies describing the molecular mechanisms involved in the antibacterial and antifungal effects elicited by SBs and CBSs as well as SB- and CBS-based nanoparticles.

\section{Schiff Bases as Antimicrobial Agents}

The antibacterial and antifungal activity of some SBs has been reported. The minimal inhibitory concentration (MIC) and/or inhibition zone diameter (IZD) are given.

\subsection{Schiff Bases with Antibacterial Activity}

A recent work by Hassan et al. (2019) [47] on SBs derived from 5-aminopyrazoles, namely 5-(benzylideneamino)-3-(4-methoxyphenylamino)- $N$-phenyl-1 $H$-pyrazole-4-carboxamides, showed their antimicrobial activity against multidrug-resistant bacteria (MDRB). In particular, compounds 1-3 (Table 1) were more active than ciprofloxacin against Grampositive Staphylococcus epidermidis (MIC $=7.81 \mu \mathrm{g} / \mathrm{mL}$ versus $15.62 \mu \mathrm{g} / \mathrm{mL}$ of ciprofloxacin), while compound 4 had the same activity of the reference against Enterococcus faecalis (MIC $=7.81 \mu \mathrm{g} / \mathrm{mL}$ ), which is a Gram-positive organism responsible for serious infections in humans [48]. Interestingly, compounds $\mathbf{2}$ and $\mathbf{3}$ were also active against Gram-negative Acinetobacter baumanni, showing the same MIC values of ciprofloxacin (MIC $=15.62 \mu \mathrm{g} / \mathrm{mL}$ ). Moreover, in silico ADMET studies were carried out. Enzymatic assays and molecular docking revealed that compound 3 exerted a strong inhibitory activity against $S$. aureus DNA gyrase and dihydrofolate reductase kinases.

Recently, Gümüş et al. (2020) [49] described two series of SB derivatives with anthraceneand pyrene-based units, which were synthesized and evaluated for their antibacterial activity against Gram-negative Bacillus cereus, E. coli and Pseudomonas aeruginosa. These experiments were performed by using the disk diffusion method taking tetracycline (30 $\mu \mathrm{g})$ and streptomycin $(10 \mu \mathrm{g})$ discs as positive controls. DNA binding activities were also tested by agarose gel electrophoresis, in which DNA molecules behave in accordance with their mass, charge and shape. As a result of binding the compounds to calf thymus DNA (CT-DNA), free DNA moves faster on the gel as it is smaller in respect to bound DNA. Of note, compounds 5 and 6 (E)-2-((anthracen-1-ylimino)methyl)quinolin-8-ol and (E)-2-((pyren-1-ylimino)methyl)pyridin-3-ol, respectively, which were found to be stably bound to CT-DNA, showed antibacterial activity against Bacillus cereus and E. coli.

Erturk et al. (2020) [50] synthesized two SBs, namely 4-((8-hydroxyquinolin-2yl)methylene)amino)-1,5-dimethyl-2-phenyl-1,2-dihydro-3H-pyrazol-3-one and 4-(((10chloroanthracen-9-yl)methylene)amino)-1,5-dimethyl-2-phenyl-1,2-dihydro-3H-pyrazol-3one (7 and 8, respectively), that were studied for their antimicrobial and antioxidant properties. Both compounds proved high antibacterial activity against Gram-positive bacteria Micrococcus luteus and S. aureus (MIC $=25 \mu \mathrm{g} / \mathrm{mL}$ and $12.5 \mu \mathrm{g} / \mathrm{mL}$, respectively, versus MIC $=100 \mu \mathrm{g} / \mathrm{mL}$ and $12.5 \mu \mathrm{g} / \mathrm{mL}$ of ampicillin). In addition, compound 8 exhibited high antifungal potential against fungi Aspergillus niger (MIC $=12.5 \mu \mathrm{g} / \mathrm{mL}$ versus MIC $=12.5 \mu \mathrm{g} / \mathrm{mL}$ of nystatin). They also showed antiproliferative activity against the MCF-7 human breast cancer cell line $\left(\mathrm{IC}_{50}<0.1 \mathrm{mM}\right.$ and $\mathrm{IC}_{50}=0.14 \mathrm{mM}$ for 7 and 8 , respectively).

In the study of Mishra et al. (2020) [51] the synthesis and antibacterial evaluation of two SB ligands comprising benzothiazole derivatives, namely $\left(N, N^{\prime}, E, N, N^{\prime} E\right)-N, N^{\prime}-(1,3-$ phenylenebis(methanylylidene))bis(5-nitrobenzo[d]thiazoL2-amine (9) and $\left(N, N^{\prime}, E, N, N^{\prime} E\right)$ $N, N^{\prime}$-(1,3-phenylene-bis(methanylylidene))bis(5-methylthiazo-L2-amine (10) and their lanthanide (III) complexes were described. Ligands showed antibacterial activity against 
S. aureus causing skin infection and food poisoning and pimple-causing Propionic bacteria acnes. Of note, the complexes were more active than SBs alone.

Yusuf et al. (2020) [52] reported the synthesis and antimicrobial evaluation of three SBs, (E)-1-(2-nitrophenyl)- $N$-(o-tolyl)methanimine (11), (E)-2-isopropyl- $N$-(2-nitrobenzylidene) aniline (12) and (E)-2-((2-nitrobenzylidene)amino)phenol (13). Compounds 11-13 were tested against E. coli, Salmonella typhimurium and P. aeruginosa as shown in Table 1 . Then, compounds 11-13 were docked into the active site pocket as observed experimentally of crystalized structures from E. coli, S. typhimurium, P. aeruginosa and S. aureus. Compound 12 showed the highest inhibitory activity against the Gram-negative bacteria S. thyphymurium and $P$. aeruginosa (MIC $=15.625 \mu \mathrm{g} / \mathrm{mL}$ and $7.81 \mu \mathrm{g} / \mathrm{mL}$, respectively) compared to the reference drug (chloramphenicol: $\mathrm{MIC}=31.25 \mu \mathrm{g} / \mathrm{mL}$ and $62.50 \mu \mathrm{g} / \mathrm{mL}$, respectively).

Interesting findings on P. aeruginosa were also reported by Chemchem et al. (2020) [53] for twelve isatin SBs obtained by green synthesis. The compounds were studied against standard and clinical bacterial strains by the agar-well diffusion method. Compound 14 and 15 revealed the lowest MIC $(625 \mu \mathrm{g} / \mathrm{mL})$ against standard S. aureus 25923 and Klebsiella pneumoniae 700,603, respectively, while the reference compound colistin was inactive. When tested against $P$. aeruginosa clinical bacterial strains, compounds 16 and 14 were the most active, showing an MIC value of $78 \mu \mathrm{g} / \mathrm{mL}$ with a large IZD (24 mm and $15 \mathrm{~mm}$, respectively), compared to the antibiotic fosfomycin (IZD $=16 \mathrm{~mm}$ ). QSAR studies showed that increased hydrophobic character associated with decreased dipole moment led to higher antibacterial activity against the standard K. pneumoniae strain.

Warad et al. (2020) [54] reported the synthesis of three SBs and their antibacterial evaluation by means of the disk diffusion test. The compounds showed low activity with respect to gentamicin. The most interesting compound was 2-(piperazin-1-yl)-N(thiophen-2-ylmethylene)-ethanamine (17). The most sensitive isolates to this compound were Gram-positive S. aureus and methicillin-resistant S. aureus (MRSA), as shown in Table 1, compared to gentamicin (IZD $=25$ and $24 \mathrm{~mm}$, respectively) and $P$. aeruginosa (gentamicin, IZD = $16 \mathrm{~mm}$ ).

Bayeh at al. (2020) [55] described the synthesis of three SBs and their antimicrobial activities compared to ciprofloxacin and chloramphenicol, as references. Among the SBs, 18 showed higher activity (IZD $=32 \mathrm{~mm}$ ) than the references against Gram-positive $S$. epidermidis (IZD = 24 and $26.7 \mathrm{~mm}$ for ciprofloxacin and chloramphenicol, respectively) and against Gram-negative P. aeruginosa (IZD = 21.3 and $27.3 \mathrm{~mm}$ for ciprofloxacin and chloramphenicol, respectively), whereas compound 19 was more active against $S$. aureus $(\mathrm{IZD}=32.5 \mathrm{~mm})$ in respect to both ciprofloxacin and chloramphenicol $(\mathrm{IZD}=24$ and $26.3 \mathrm{~mm}$, respectively).

Anwar et al. (2020) [56] described the synthesis of SBs of amikacin and their screening for in vitro antibacterial activity by the well diffusion method against Bacillus megaterium, Bacillus subtilis, Stenotrophomonas maltophilia, S. aureus, M. luteus, Serratia marcescens and E. coli. The authors concluded that derivatives of amikacin with aromatic rings were more active antibacterials than those with an aliphatic side chain. The most interesting compounds were 20 and 21, which showed higher activity against $S$. aureus (IZD = 37 and $321 \mathrm{~mm}$, respectively) than amikacin $(\mathrm{IZD}=29 \mathrm{~mm})$ and $E$. coli $(\mathrm{IZD}=37$ and $38 \mathrm{~mm}$ versus amikacin IZD = $25 \mathrm{~mm})$.

Salihović et al. (2021) [57] described the synthesis of two SBs deriving from L-cysteine, namely 2-((2-chlorobenzylidene)amino)-3-mercaptopropanoic acid (22) and 3-mercapto2-((2-methoxybenzylidene)amino)propanoic acid (23), and an antimicrobial activity evaluation against five Gram-positive (S. aureus, B. subtilis, Clostridium sporogenes, M. luteus and Microccocus flavus), five Gram-negative (E. coli, P. aeruginosa, Proteus hauseri, K. pneumoniae, Salmonella enterica and subsp. enterica serovar Enteritidis) standard bacterial strains and some yeasts (A. brasiliensis, S. cerevisiae and C. albicans). Compound 22 showed higher antimicrobial activity against all tested bacteria $(\mathrm{MIC}=1.284 \mathrm{mM})$, while compound 23 showed lower activity (MIC $=2.612 \mathrm{mM}$ ) compared to amikacin (MIC between 0.08 and $0.111 \mathrm{mM}$ ). The higher antifungal activity was found against $A$. brasiliensis for 
both compounds (MIC $=1.284 \mathrm{mM}$ and $1.306 \mathrm{mM}$, respectively) versus amphotericin $\mathrm{B}$ $(\mathrm{MIC}=0.044 \mathrm{mM})$.

Srinivasan et al. (2021) [58] described the synthesis and antibacterial evaluation of two pyrene-based SBs, 4-[(5-pyren-1-yl-thiophen-2-ylmethylene)-amino]-phenol (24) and 4-[(4-pyren-1-yl-benzylidene)-amino]-phenol (25), against two strains of P. aeruginosa, 9027 and 27853. The authors determined that $\mathbf{2 4}$ was more active as an antibacterial when compared to 25; however, MIC or IZD values were not given. The treatment with compound 24 showed a minimum effect on the cell viability at a concentration range from 100 to $500 \mu \mathrm{g} / \mathrm{mL}$. It was only found to be cytotoxic, i.e., almost $70 \%$ cell growth inhibition was evident, at a high concentration of 24 , i.e., $1000 \mu \mathrm{g} / \mathrm{mL}$.

Sumrra et al. (2021) [59] reported a study on two mono-SBs, 4-[(5-amino- $1 H-1,2,4-$ triazol-3-yl)imino]methylbenzene-1,3-diol (26) and 2-[(5-amino-1H-1,2,4-triazol-3-yl)imino] methyl\}-6-methoxyphenol (27), and one bis-SBs, 2,2'-\{1H-1,2,4-triazole-3,5-diylbis [nitrilomethylylidene]\}bis(6-methoxyphenol) (28), along with their metal complexes. An antibacterial activity evaluation was carried out for five bacterial strains (Halomonas halophila, Chromohalobacter israelensis, E. coli, Chromohalobacter salexigens and Halomonas salina). They exhibited antibacterial activity, and $\mathbf{2 6}$ was found to be more active against $C$. salexigens and $H$. salina and $\mathbf{2 7}$ was found to be more active against $E$. coli and C. salexigens, while 28 showed higher activity against E. coli and H. salina. Streptomycin, which was used as a reference, showed IZD values between 20 and $23 \mathrm{~mm}$.

Ragi et al. (2021) [60] recently studied two SBs, 2,2'-(5,5-dimethylcyclohexane-1,3diylidene)bis(azan-1-yl-1-ylidene)diphenol (29) and $N, N^{\prime}$-(5,5-dimethylcyclohexane-1,3diylidene)dianiline (30), against $S$. aureus and its target proteins after pre-filtering the druglike properties of the compounds using the Lipinski rule of five. The compounds showed activity similar to that of ampicillin against $S$. aureus (IZD $=26$ and $25 \mathrm{~mm}$, respectively, versus $30 \mathrm{~mm}$ of ampicillin, all measured at $500 \mu \mathrm{g} \mathrm{disc}^{-1}$ concentration). The mechanisms by which these molecules can inhibit the growth of $S$. aureus were established by molecular docking studies on six different target proteins of S. aureus: sortase-A, clumping factor A (ClfA), dihydrofolate reductase (DHFR), DNA gyrase, undecaprenyl diphosphate synthase (UPPS) and dehydrosqualene synthase (CrtM) (PDB ID: 1T2P, 1N67, 2W9S, 3U2D, 4H8E and $2 \mathrm{ZCO}$, respectively). Both SBs showed good binding affinity for the target protein DHFR, although in different sites. Thus, the authors suggested that the appreciable growthinhibitory power exerted by compounds $\mathrm{DmChDp}$ and $\mathrm{DmChDa}$ against $S$. aureus could be related to the deactivation of dihydrofolate reductase [58].

Singhal et al. (2021) [61] studied 15 novel bis indole-based SBs as antibacterials. Comparative analyses against $S$. aureus and E. coli showed a higher inhibition of bis-SBs than the reference drug ciprofloxacin and their mono counterparts, the mono-SBs. The hexyl linker-based bis-SBs 31-33 depicted higher antibacterial action at $50 \mu \mathrm{g} / \mathrm{mL}$, and the inhibitory effect increased with the increasing number of carbon atoms on the linker chain. Specifically, bis-SB 33 was the most active, showing MIC values of 37 and $34 \mathrm{~mm}$ against E. coli and S. aureus, respectively, compared to ciprofloxacin (IZD $=14 \mathrm{~mm}$ and $17 \mathrm{~mm}$, respectively). Molecular docking studies on this compound were carried out with CT-DNA (PDBID:1BNA) and SARS-CoV-2 Mpro (3CL protease, PDBID:6LU7) via ultraviolet-visible and fluorescence spectroscopy techniques. Compound $\mathbf{3 3}$ proved its efficacy as a potential DNA binder and antiviral agent. 
Table 1. Schiff bases with antibacterial activity.

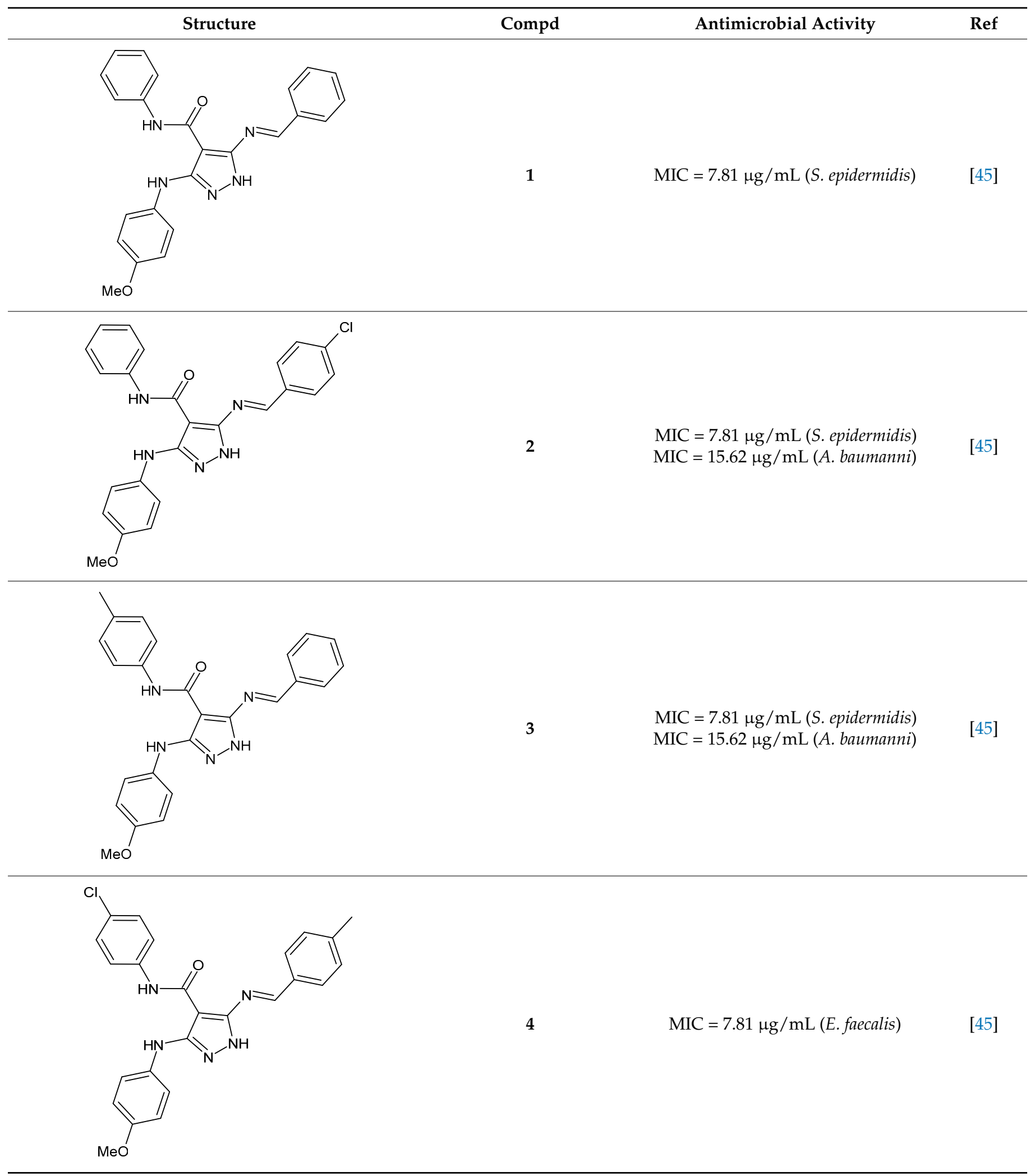


Table 1. Cont.

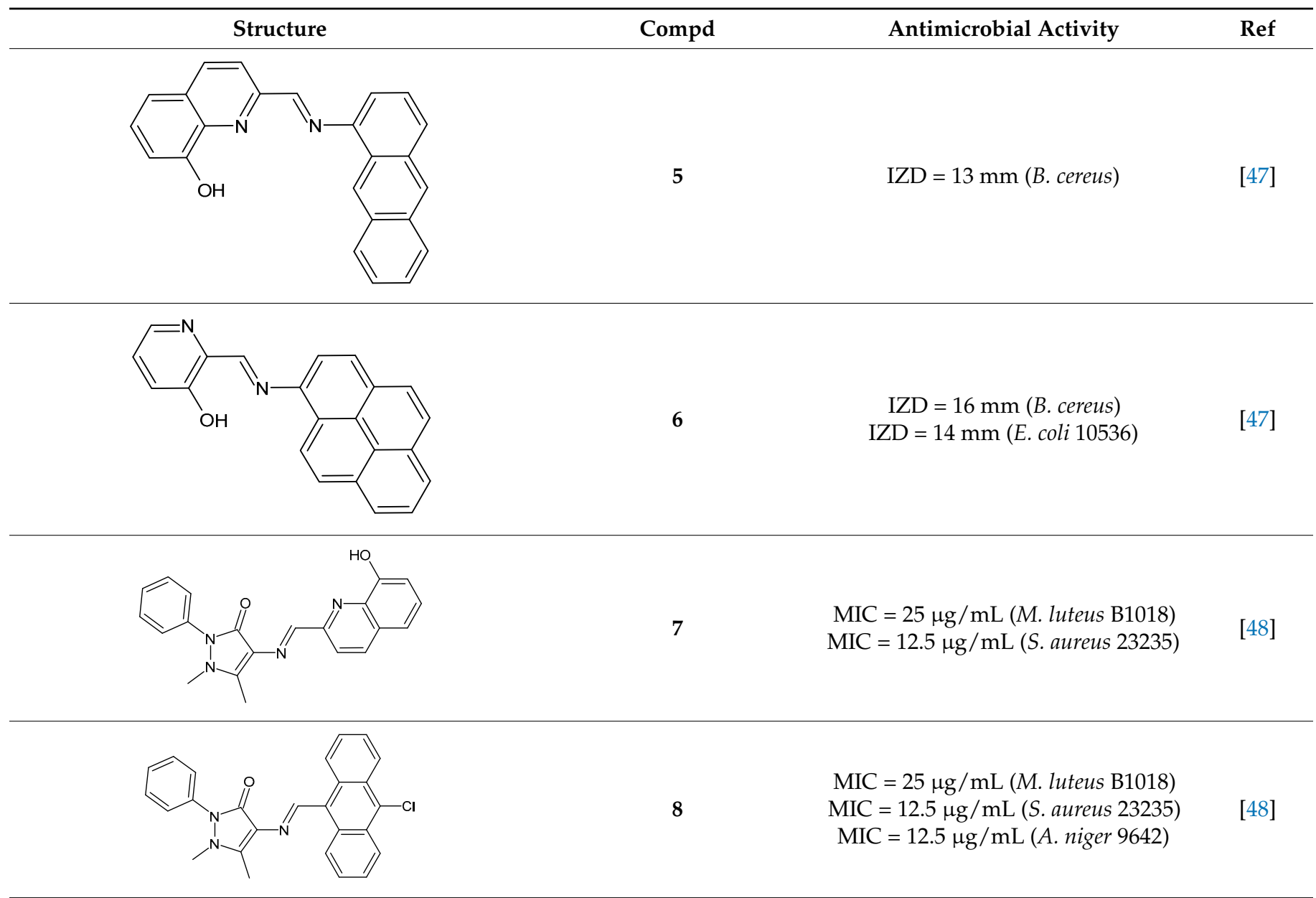<smiles>O=[N+]([O-])c1ccc2sc(/N=C/c3cccc(/C=N/c4nc5cc([N+](=O)[O-])ccc5s4)c3)nc2c1</smiles><smiles>Cc1cnc(/N=C/c2cccc(/C=N/c3ncc(C)s3)c2)s1</smiles><smiles>Cc1ccccc1/N=C/c1ccccc1[N+](=O)[O-]</smiles>

MIC $=250 \mu \mathrm{g} / \mathrm{mL}$ (E. coli)<smiles>CC(C)c1ccccc1/N=C/c1ccccc1[N+](=O)[O-]</smiles>

$$
\begin{gathered}
\mathrm{MIC}=125 \mu \mathrm{g} / \mathrm{mL}(\text { E. coli }) \\
\mathrm{MIC}=15.625 \mu \mathrm{g} / \mathrm{mL} \\
\text { (S. thyphymurium) }
\end{gathered}
$$
$\mathrm{MIC}=7.81 \mu \mathrm{g} / \mathrm{mL}($ P. aeruginosa $)$ 
Table 1. Cont.

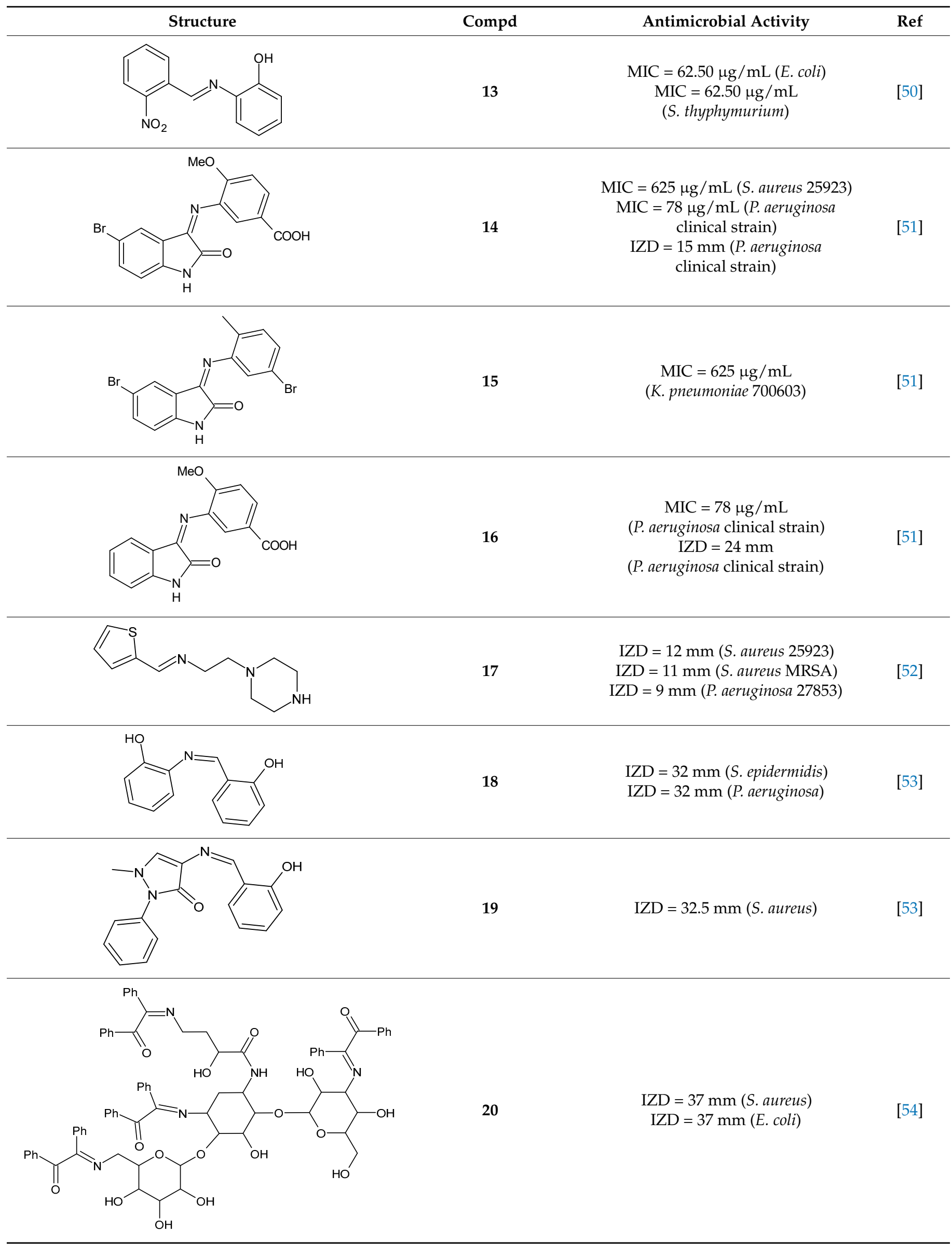


Table 1. Cont.

Structure<smiles>O=C(O)C(CS)/N=C/c1ccccc1Cl</smiles>

$\mathrm{MIC}=1.284 \mathrm{mM}$ (S. aureus $6538 ;$
B. subtilis $6633 ;$ C. sporogenes 19404

M. luteus 4698; M. flavus 10240)

$\mathrm{MIC}=1.284 \mathrm{mM}$ (E. coli 25922;

S. aeruginosa 9027; Proteus hauseri

13315; K. Pneumoniae 10031;

Salmonella enterica subsp. enterica serovar Enteritidis 13076)

$$
\mathrm{MIC}=1.284 \mathrm{mM}
$$

(A. brasiliensis 16,404)

$\mathrm{MIC}=2.612 \mathrm{mM}$ (S. aureus 6538;

B. subtilis 6633; C. sporogenes 19404;

M. luteus 4698; M. flavus 10240)

MIC = $2.612 \mathrm{mM}$ (E. coli 25922;<smiles>COc1ccccc1/C=N/C(CS)C(=O)O</smiles>

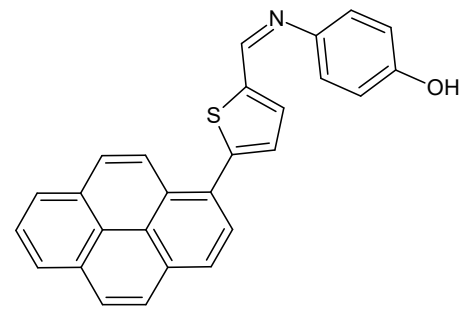

MIC and/or IZD not given

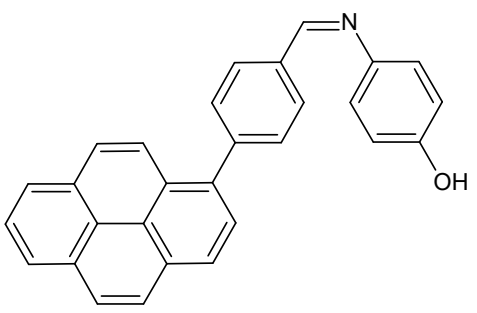<smiles>Nc1nc(/N=C/c2ccc(O)cc2)n[nH]1</smiles>

$\mathrm{IZD}=12 \mathrm{~mm}(\mathrm{C}$. salexigens and H. salina) $\mathrm{IZD}=10 \mathrm{~mm}(\mathrm{H}$. halophila $)$ 
Table 1. Cont.

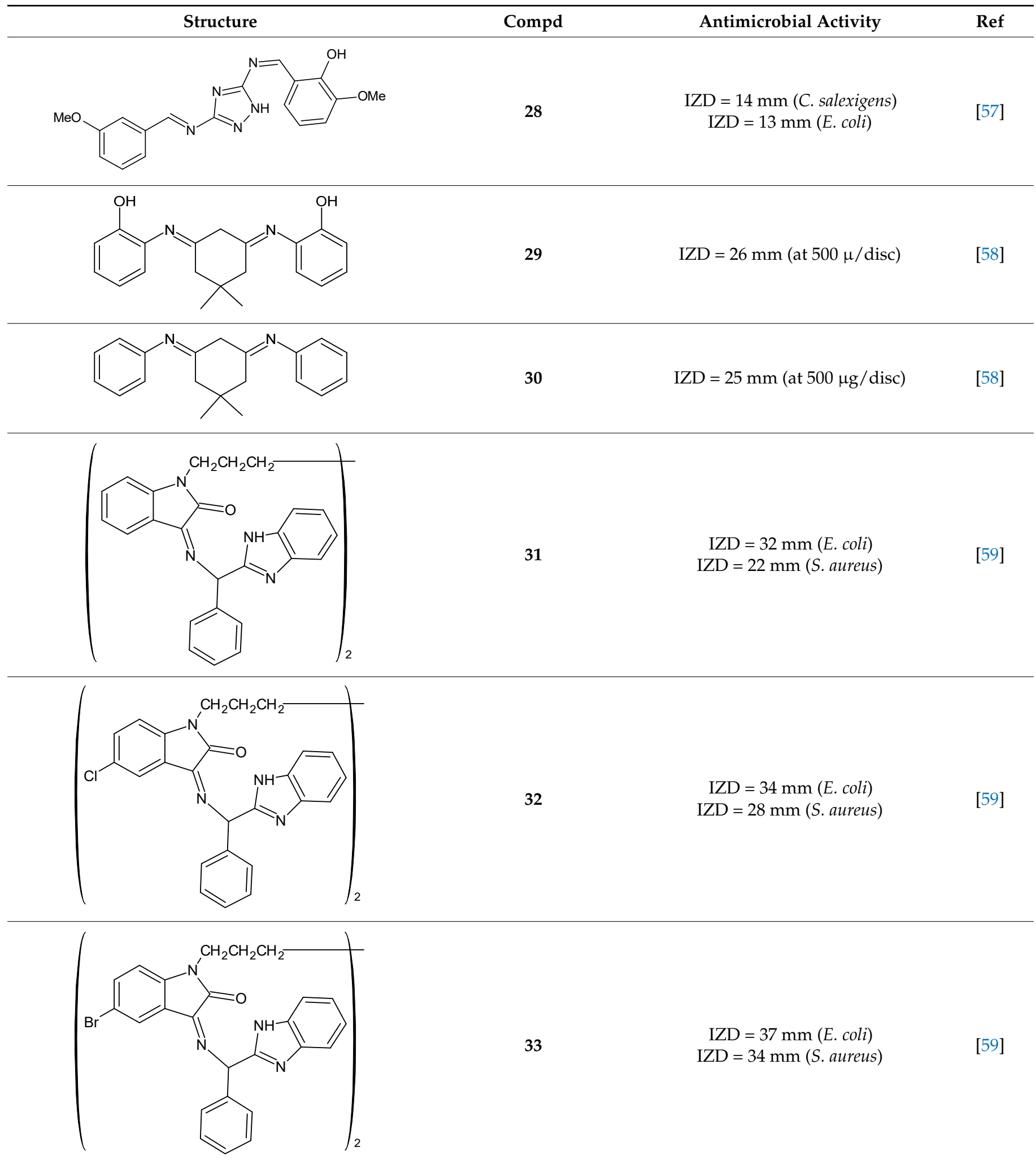

A recent study by Aragón-Muriel et al. (2021) [62] investigated the antibacterial potential of four benzimidazole-based Schiff bases and their metal complexes against two Gram-positive strains (S. aureus 25923, Listeria monocytogenes 19115) and two Gramnegative strains (E. coli 25922, P. aeruginosa 27583). As generally observed, the activity of 
the complexes was higher than that of SBs alone. Moreover, isomerism in SBs seemed to play a crucial role, as is often the case for compounds with biological activity [63]. The major activity found in the study by Aragón-Muriel et al. (2021) [62] was shown by 34 and 35 (MIC = $250 \mathrm{ng} / \mathrm{mL}$ against $S$. aureus versus $0.5 \mathrm{ng} / \mathrm{mL}$ of ciprofloxacin). Despite the low activity of SBs, this study provided novel insights into the mechanisms through which the compound exerts antibacterial action, suggesting that interactions with the bacterial membrane or interactions with DNA could be involved. The types of interactions that occurred between nucleic acid and new compounds was studied by UV/V spectrophotometry. Differences can be found in the tautomers deriving from the keto-enol equilibrium (Figure 2). The interaction of DNA with these systems would result in the stabilization of one of the tautomers when a DNA-compound complex is formed. The interaction with DNA seemed to favor the keto form of 34, while the union of 35 with DNA strands stabilized the enol form of 35.

Enol

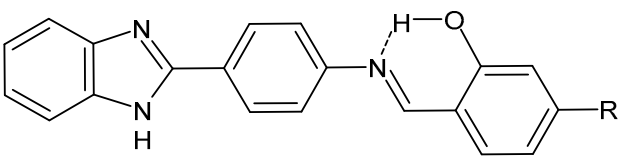<smiles>C=[Tl]</smiles>

34: $\mathrm{R}=\mathrm{H}$

35: $\mathrm{R}=\mathrm{OH}$

Keto

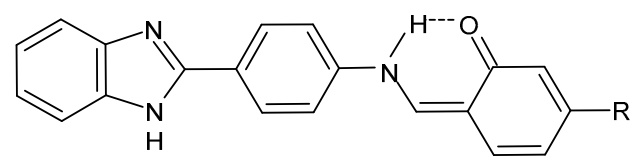

Figure 2. Keto-enol equilibrium of 34 and 35 SBs.

\subsection{Schiff Bases with Antifungal Activity}

All the data described in this paragraph are summarized in Table 2. Some studies did not report MICs or IZDs but did provide inhibitory indexes (IIs).

Magalhães et al. (2020) [64] described the synthesis and the in vitro antifungal evaluation of 23 cinnamyl SBs. Six of them showed antifungal activities against strains of Candida, Aspergillus, Fonsecaea and, specifically, Cryptococcus species. Compounds 36 and 37 showed MIC values more than two-fold lower than that of the reference fluconazole against all the Cryptococcus neoformans strains ( $\mathrm{MIC}=1.33 \mu \mathrm{g} / \mathrm{mL}$ and $1.4 \mu \mathrm{g} / \mathrm{mL}$, respectively, versus fluconazole, $5.2 \mu \mathrm{g} / \mathrm{mL}$ ) and Cryptococcus gattii strains (MIC $=5.3 \mu \mathrm{g} / \mathrm{mL}$ and $2.8 \mu \mathrm{g} / \mathrm{mL}$, respectively, versus fluconazole, $9.2 \mu \mathrm{g} / \mathrm{mL}$ ), while cinnamyl SB 38 was as potent as fluconazole against all strains from both Cryptococcus species. No significant cytotoxic effects were observed for SBs against human lung (MRC-5, human fetal lung fibroblast), kidney (HEK 293, human embryonic kidney) or red blood cells, all presenting selective indexes higher than 10 .

Chen et al. (2020) [65] described a structural modification of inulin by SBs in order to improve its biological activity. The antifungal studies against three kinds of plant pathogenic fungi (Botrytis cinerea, Fusarium oxysporum f. sp. cucumerium Owen and Phomopsis asparagi), according to Guo's method [66], showed that synthetic inulin derivatives demonstrated a broad antifungal spectrum. At $1.6 \mathrm{mg} / \mathrm{mL}$, the IIs of 39 were $93 \%, 83 \%$ and $82 \%$ against B. cinerea, F. oxysporum f. sp. cucumerium Owen and P. asparagi, respectively. The lipophilic characteristics of $\mathbf{3 9}$ due to the presence of the benzene ring and the acetyl groups allow this compound to easily penetrate into the cell, leading to apoptosis. Moreover, the new inulin derivatives modified with the Schiff bases showed an excellent metal binding property, suppressing the growth of microbes by their interaction with cellular components.

A recent study by Hamad et al. [67] described the synthesis of SBs of sulphonamides and their antifungal activity against multidrug-resistant Candida auris, an emerging fungal pathogen with a high mortality rate, which is difficult to identify and carries considerable 
risks of healthcare outbreaks [68]. In 2020, diverse cases of candidemia outbreaks related to COVID-19 in intensive care units in hospitals and severe fungal coinfections have been reported worldwide [69]. The SBs of sulphonamides were first tested against a multispecies panel of Candida strains (C. auris TDG1912, Candida albicans NCPF3281 and NCPF3179, Candida glabrata NCPF8018, Candida krusei NCPF3876, Candida tropicalis NCPF8760 and Candida parapsilosis NCPF3209). Compound 40 showed interesting MIC values against almost all the strains in the range of $4-32 \mu \mathrm{g} / \mathrm{mL}$ (versus $0.5->128 \mu \mathrm{g} / \mathrm{mL}$ of fluconazole). Thus, it was tested against a larger panel of multidrug-resistant C. auris strains (TDG2506, TDG2512, TDG1102, TDG2211, NCPF8984, NCPF8977 and NCPF8971), and its antifungal activity was confirmed with MICs of 4-16 $\mu \mathrm{g} / \mathrm{mL}$, which are very low considering that in four cases (TDG2506, TDG1102, TDG2211 and NCPF8984) the MIC value for fluconazole was $\geq 128 \mu \mathrm{g} / \mathrm{mL}$. Compound 41 showed the same results of 40 only on the extended panel [64].

Bhagwatrao Biradar et al. (2021) [70] reported the synthesis of SBs derived from dehydroacetic acid (DHA) and evaluated their antimicrobial activity. The most interesting compounds were 42, showing an IZD $=19 \mathrm{~mm}$ against $A$. niger (griseofulvin IZD $=22 \mathrm{~mm}$ ) and 43 against $C$. albicans (IZD $=21 \mathrm{~mm}$ versus griseofulvin, IZD $=25 \mathrm{~mm}$ ).

Table 2. Schiff bases with antifungal activity.

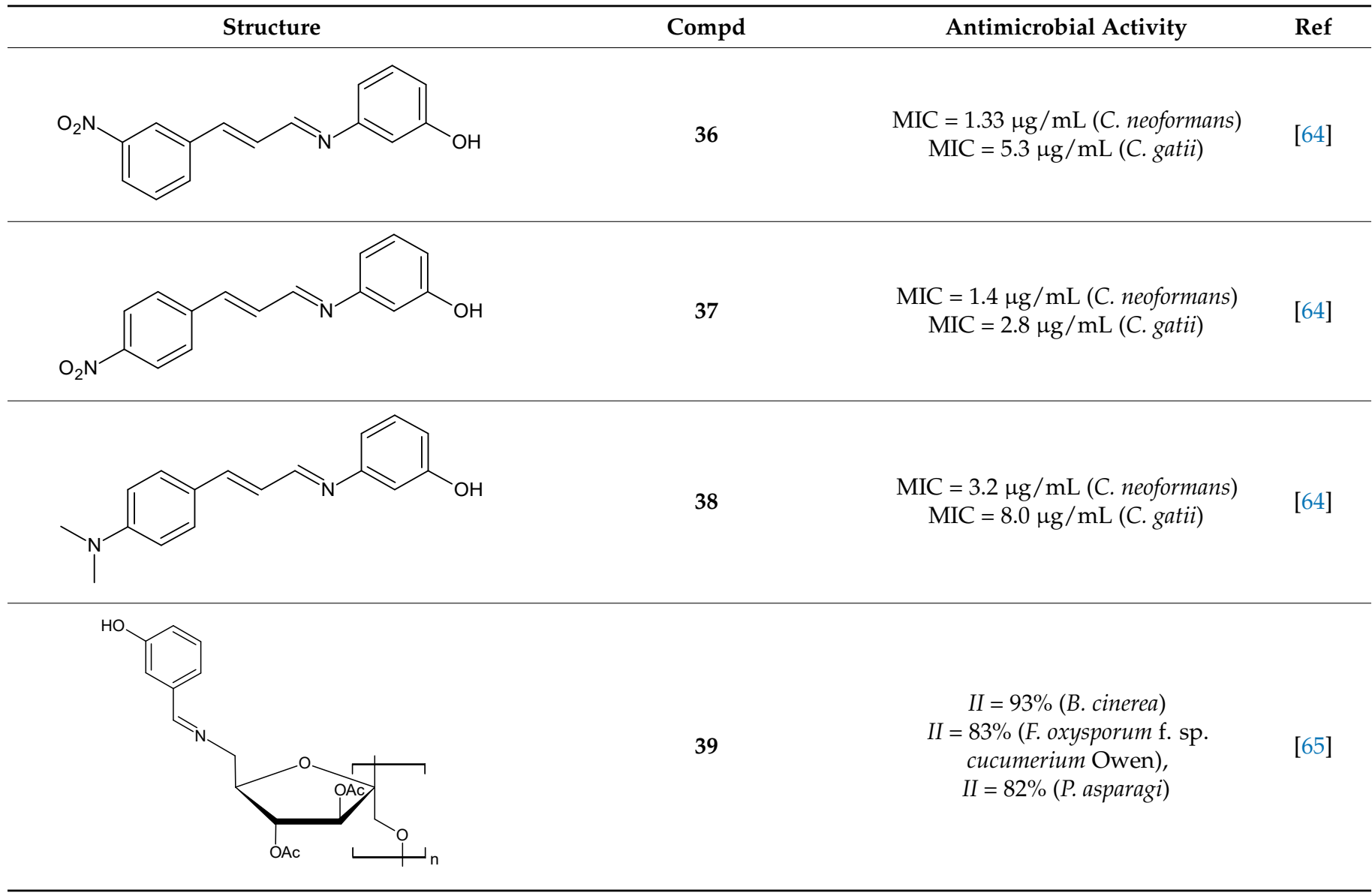


Table 2. Cont.

\begin{tabular}{|c|c|c|c|}
\hline Structure & Compd & Antimicrobial Activity & Ref \\
\hline (OH & 40 & $\begin{array}{c}\text { MIC }=16 \mu \mathrm{g} / \mathrm{mL}(C \text {. auris } \\
\text { TDG1912; C. albicans NCPF3281) } \\
\text { MIC }=16-32 \mu \mathrm{g} / \mathrm{mL} \\
\text { (C. albicans } \mathrm{NCPF} 3179) \\
\text { MIC }=4-8 \mu \mathrm{g} / \mathrm{mL} \\
\text { (C. } \text { glabrata } \mathrm{NCPF} 8018) \\
\mathrm{MIC}=8-16 \mu \mathrm{g} / \mathrm{mL} \\
\text { (C. auris NCPF8971) } \\
\text { MIC }=16 \mu \mathrm{g} / \mathrm{mL} \\
\text { (C. auris TDG2512, TDG2506, } \\
\text { NCPF8984, NCPF8977) } \\
\text { MIC }=16-32 \mu \mathrm{g} / \mathrm{mL} \\
\text { (C. auris TDG1102, TDG2211) }\end{array}$ & [67] \\
\hline
\end{tabular}

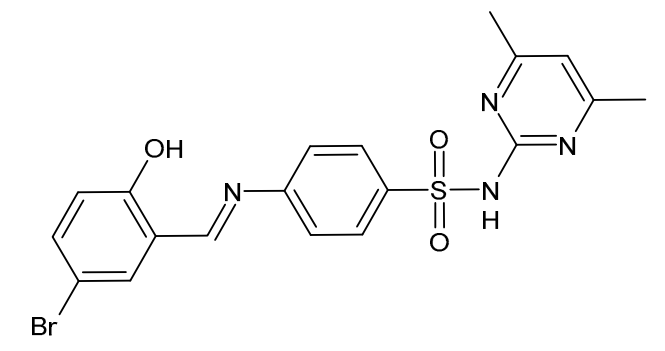

$\mathrm{MIC}=8-16 \mu \mathrm{g} / \mathrm{mL}$

(C. auris NCPF8971)

$\mathrm{MIC}=16 \mu \mathrm{g} / \mathrm{mL}$

41

(C. auris TDG2512, TDG2506,

NCPF8984, NCPF8977)

$\mathrm{MIC}=16-32 \mu \mathrm{g} / \mathrm{mL}$

(C. auris TDG1102, TDG2211)

\section{Chitosan-Based Schiff Bases (CBSs)}

Chitosan ( $N$-deacetylated product of chitin) is a natural biopolymer composed of $\beta$-D-glucosamine and $N$-acetyl- $\beta$-D-glucosamine units with a 1,4-linkage. Chitosan is an attractive material because of its properties such as immunological activity, biocompatibility, low toxicity and biodegradability. Chitosan is insoluble in water and most organic solvents, which seriously limits its application. CBSs result from the chemical modification of chitosan via imine functionalization $\left(R R^{\prime} C=N-R^{\prime \prime} ; R=\right.$ alkyl/aryl, $R^{\prime}=H /$ alkyl/aryl and $\mathrm{R}^{\prime \prime}=$ chitosan ring). They are usually synthesized by the Schiff condensation reaction between chitosan's amino groups and carbonyl compounds with the removal of water molecules. The antibacterial applications of chitosan derivatives are numerous [71,72]. Recently, two chitosan Schiff bases were used for the removal of $\mathrm{Cr}(\mathrm{VI})$ from wastewater with high efficiency [73,74]. Antimicrobial studies of CBSs are reported in Table 3.

Barbosa et al. (2017) [75] described several biopolymeric Schiff bases of chitosan and different salicylaldehydes and their complexes with palladium(II) and platinum(II). They were tested for antimicrobial activity in vitro against two common bacterial and fungal plant pathogens, Pseudomonas syringae pv. tomato and Fusarium graminearum, respectively, and for their antiproliferative activity against human MCF-7 breast cancer cells. Compared to the unmodified chitosan, CBSs and their complexes had higher antibacterial effects 
against $P$. syringae but were highly toxic against MCF-7 cells. In particular, the MIC value of 44 was $25 \mu \mathrm{g} / \mathrm{mL}$ (versus $>50 \mu \mathrm{g} / \mathrm{mL}$ of purified chitosan). The antifungal effects against $F$. graminearum were less pronounced compared to the nonmodified chitosan (44, MIC $=50 \mu \mathrm{g} / \mathrm{mL}$ versus $30 \mu \mathrm{g} / \mathrm{mL}$ of purified chitosan), suggesting diverse modes of action for the two fungal species.

Table 3. Structure and antibacterial activity of chitosan-based Schiff bases.

\begin{tabular}{rlr}
\hline Structure & Compd & Antimicrobial Activity \\
Ref
\end{tabular}

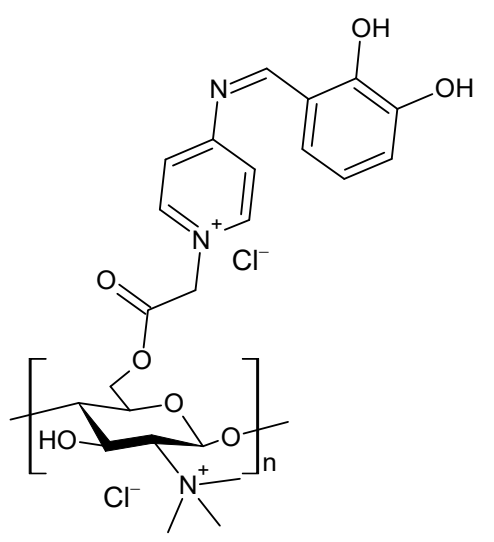

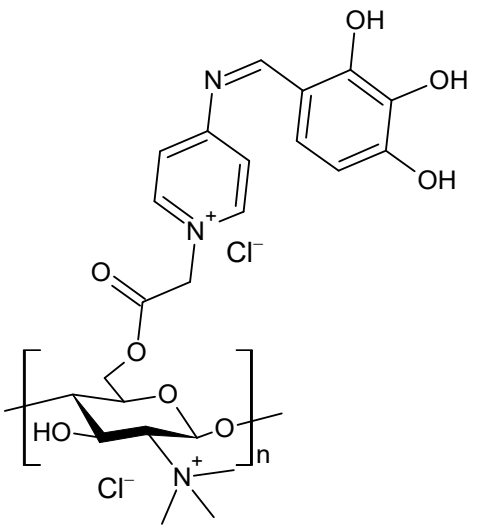

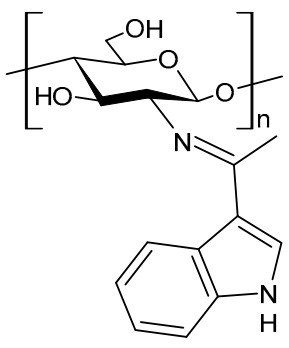

$\mathrm{IZD}=17.7 \mathrm{~mm}($ E. coli $)$ $\mathrm{IZD}=17.2 \mathrm{~mm}($ P. aeruginosa $)$ 
Table 3. Cont.

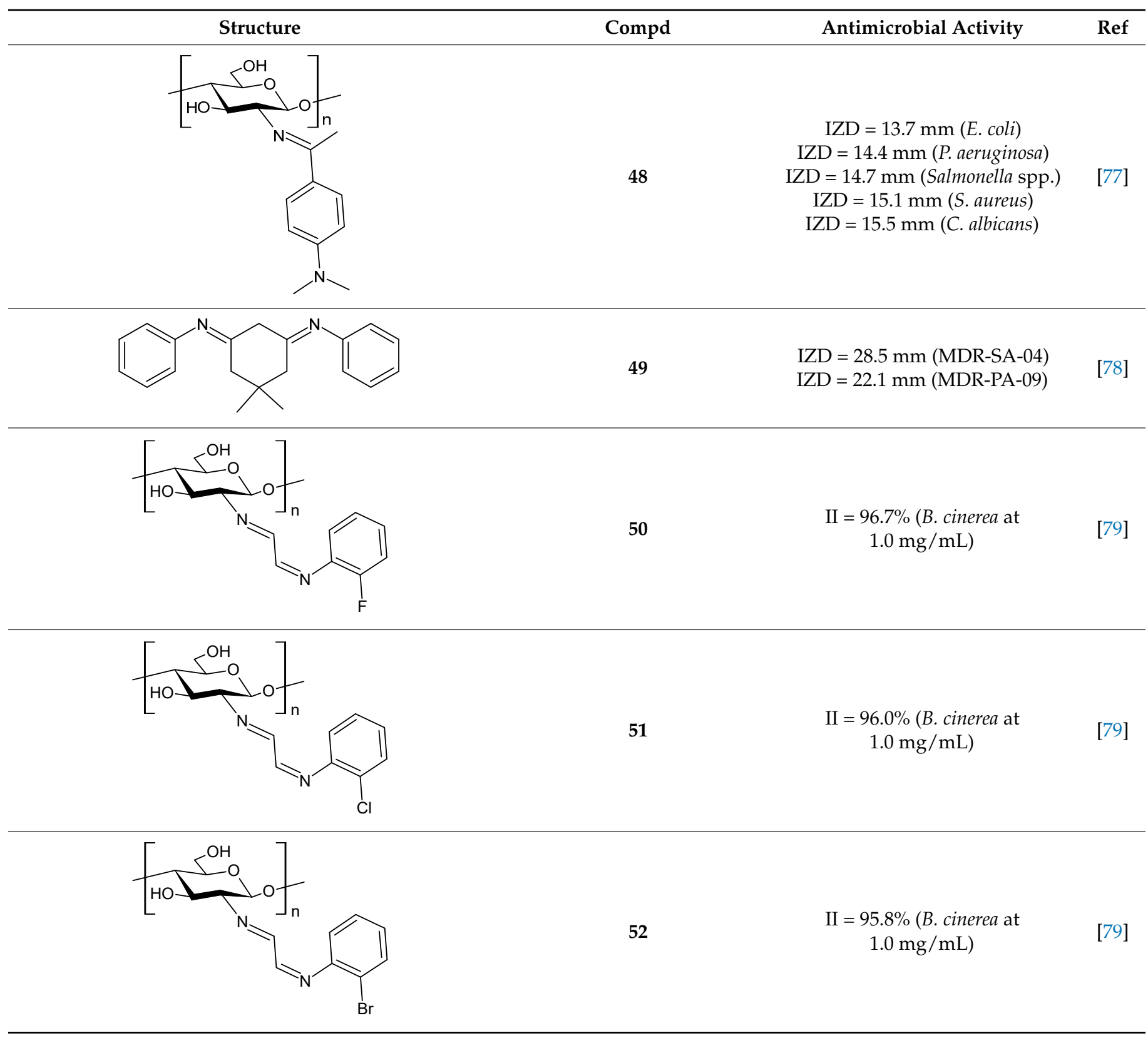

Wei et al. (2019) [76] synthesized eight CBSs and quaternary ammonium salts in order to improve the antioxidant and antifungal activity of chitosan. The antifungal activity against $F$. oxysporum f. sp. cucumerium, B. cinerea and F. oxysporum f. sp. niveum was evaluated using a mycelium growth rate test. CBSs exhibited enhanced antifungal activity when compared to chitosan, especially at $1.0 \mathrm{mg} / \mathrm{mL}$. Chitosan II was $16.9 \%$ at $1.0 \mathrm{mg} / \mathrm{mL}$. The most interesting were 6-[4-(2,3-dihydroxyl-benzimide) pyridine] acetyl-2$\mathrm{N}, \mathrm{N}, \mathrm{N}$-trimethyl-chitosan chloride (45) and 6-[4-(2,3,4-trihydroxyl-benzimide) pyridine] acetyl-2-N,N,N-trimethyl-chitosan chloride (46), which showed IIs $>90.0 \%$ at $1.0 \mathrm{mg} / \mathrm{mL}$ against $F$. oxysporum f. sp. cucumerium and B. cinerea. The chitosan derivatives also showed stronger antioxidant activity than chitosan. It was suggested that the higher density of the positive charge contributes to the antifungal activity. The positive charge could interact with the anionic substances, such as glucan, mannan, proteins and lipids to form a lipophilic layer around the cell, which could prevent nutrient exchange in the cells. The authors 
posited that the higher antifungal activity of 45 and 46 might be due to the presence of phenolic groups.

Hassan et al. (2018) [77] described the ability of two antimicrobial chitosan SBs, 47 and 48, to boost the antimicrobial activity of native chitosan against Gram-positive bacteria (S. aureus and B. cereus), Gram-negative bacteria (E. coli, P. aeruginosa and Salmonella sp.) and $C$. albicans fungal species. The antimicrobial activity of SB 47 was significantly higher than that of SB 48 and chitosan (IZD = 11.5, 12.6, 13, 13.9, 13.6 and $11.4 \mathrm{~mm}$ (against E. coli, P. aeruginosa, Salmonella spp. and S. aureus, C. albicans) using erythromycin (IZD $=11$ and $12.6 \mathrm{~mm}$ against $E$. coli and Salmonella spp.) and nystatine (IZD $=15.2 \mathrm{~mm}$ against $C$. albicans) as reference drugs. The highest concentration of compound 47 could inhibit the growth of Gram-positive bacteria up to $99 \%$, whereas compound 48 recorded the maximum inhibition rate against Gram-positive bacteria, by approximately $82 \%$. The higher action of compound 47 on Gram-positive bacteria than Gram-negative bacteria, which appeared at $250 \mu \mathrm{g} / \mathrm{mL}$, was attributed to the difference of the cell wall structures. The cytotoxicity of the developed materials was estimated by MTT assay in fibroblast cells. The cellular toxicity of SBs I and II at $200 \mathrm{mg}$ were $5.2 \%$ and $6.3 \%$, respectively, thus substantiating their safety.

Ali et al. (2018) [78] studied a chitosan derivative, a methyl acrylate chitosan-bearing p-nitrobenzaldehyde (49) Schiff base, and examined its antibacterial activity against MDR Gram-positive bacteria MDR S. aureus (MDR-SA) and MDR Gram-negative bacteria MDR P. aeruginosa (MDR-PA), MDR K. pneumoniae (MDR-KP) and MDR E. coli (MDR-EC) by using the agar-well diffusion method. The chitosan derivative 49 showed significantly higher antibacterial activity against MDR-SA and MDR-PA compared to other bacteria. MDR S. aureus 4 (MDR-SA-04) and MDR P. aeruginosa 9 (MDR-PA-09) strains were found to be more susceptible Gram-positive and Gram-negative bacterial strains to 49 , respectively. The highest mean IZDs ranged from $15.0 \pm 0.23$ to $28.5 \pm 0.03 \mathrm{~mm}$ and from $10.5 \pm 0.03$ to $22.1 \pm 0.05 \mathrm{~mm}$, respectively. On the other hand, 49 revealed the highest antibacterial activity, showing an MIC value of $6.25 \mu \mathrm{g} / \mathrm{mL}$ for both bacterial strains. Moreover, it exhibited antibiofilm activity against MDR-PA- 09 , as assessed by using a microtiter plate. The compound also showed antioxidant and anti-inflammatory activities, as determined by the 2,2-diphenyl-2-picrylhydrazyl (DPPH) method and by albumin denaturation, membrane stabilization of red blood cells assay and proteinase inhibition methods.

Recently, Wei et al. (2021) [79] reported another work regarding the bis-Schiff bases of chitosan derivatives tested for their antifungal action against three plant pathogenic fungi (B. cinerea, Fusarium oxysporum f. sp. cucumerinum and Fusarium oxysporum f. sp. Niveum). The results show that the bis-Schiff bases of chitosan showed higher antifungal activity than chitosan, especially at $1.0 \mathrm{mg} / \mathrm{mL}$. Specifically, derivatives bearing halogeno-benzenes (50-52) showed IIs higher than $95 \%$ at $1.0 \mathrm{mg} / \mathrm{mL}$ against B. cinerea (versus chitosan $23.8 \%$ ), and this high activity was attributed to the halogen with stronger electron-withdrawing properties.

\section{Nanoformulations and Nanomedicines}

Nanotechnology has recently emerged as a very interesting field of research with countless biomedical science applications. It is described as the design, characterization and application of structures, devices and systems by monitoring shape and size at a nanometer scale ( $1 \mathrm{~nm}$ to $100 \mathrm{~nm}$ ) [80]. Silver, gold and copper nanoparticles have been widely described for their anticancer properties [81], and silver and gold nanoparticles have also shown antibacterial and antiviral activities [82,83]. In addition, experimental evidence regarding nanoparticles with Schiff bases for the diagnosis and treatment of tumors have been also reported. Some prodrug nanomedicines deriving from Schiff bases with doxorubicin and polyethylene glycol (PEG), one of the most widely used hydrophilic polymer approved by Food and Drug Administration (FDA) with negligible toxicity, have been described for their antitumor activity [84]. Moreover, the functionalization of chitosan 
nanoparticles with the anticancer 5-fluorouracil to obtain chitosan nanocarriers through Schiff base formation has been studied [85].

\subsection{Nanoparticles of Schiff Bases}

Several studies on the ability of nanoparticles to enhance antibacterial activities have also been reported. Several nanocojugates, i.e., Schiff base complexes with zinc conjugated to silver nanoparticles, showed excellent antimicrobial activity against $S$. aureus [86]. A recent work by Minhaz et al. (2020) [87] compared the activity of an SB (53) and silver nanoparticles of this compound (53-AgNPs), studied as nanoprobes. The latter exhibited significant antibacterial and anticancer activities and was also used as sensitive protocol for the detection and quantification of heavy metal $\mathrm{Hg}$ (II) in tap water. Regarding antibacterial activity, the IZDs values for $\mathbf{5 3}$ were 8.0, 9.0, 7.0 and $7.0 \mathrm{~mm}$ against $S$. aureus, B. subtilis, $P$. aeruginosa and E. coli, respectively, and 53-AgNPs achieved IZD values of 18.0, 18.0, 10.0 and $10.0 \mathrm{~mm}$, respectively (values for vancomycin were 18.0, 25.0, 12.0 and $13.0 \mathrm{~mm}$, respectively). Cytotoxicity results show that 53-AgNPs at a concentration of $100 \mathrm{mg} / \mathrm{mL}$ induced DU-145 cell toxicity and caused $94 \%$ cell death after treatment up to $72 \mathrm{~h}$. Moreover, in normal cells (L-929) death rate was lower (up to 1.5\%) as compared to cancer cells, and this was indicative of a selective action of this compound.

\subsection{Nanoparticles of Schiff Bases with Chitosan}

Biomaterials based on chitosan modified with nanoparticles have shown promising results as antibacterials [88-90]. In fact, chitosan-based nanoparticles have several advantages including efficiency, cost-effectiveness, biocompatibility, biodegradability, non-toxicity and non-immunogenicity [91].

Abdel-Monem et al. (2020) [92] described the synthesis of nanocomposites of salicylaldehyde and anisaldehyde carboxymethyl chitosan-Schiff bases (54 and 55, respectively, Table 4) also loaded with silver nanoparticles $\left(\mathbf{5 4}-\mathbf{A g N O}_{3}\right.$ and $\left.\mathbf{5 5}-\mathbf{A g N O}_{3}\right)$ and studied their antibacterial activities against Gram-positive bacteria (B. subtilis, S. aureus and Streptococcus faecalis) and Gram-negative bacteria (E. coli, Neisseria gonorrhoeae and P. aeruginosa). CMCs derivatives presented remarkable antimicrobial activity, which was increased using silver $\left(\mathrm{AgNO}_{3} 5 \%\right)$. Ampicillin was used as a reference (IZD = 20, 18, 18, 22, 20 and $17 \mathrm{~mm}$ against B. subtilis, S. aureus, S. faecalis, E. coli, N. gonorrhoeae and P. aeruginosa, respectively). SB

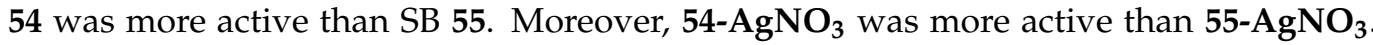

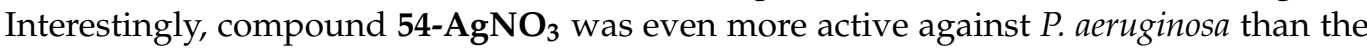
reference (ampicillin; IZD = $17 \mathrm{~mm}$ ). Cytotoxic activity was evaluated against liver HePG2 and breast MCF7 cancer cells. CMC-SBs showed lower cytotoxicity than carboxymethyl chitosan against both tumor cell lines. The cytotoxicity was even lower when considering CMC-SBs silver nanoparticles.

Recently, a CSB (56) and its CSB-NiFe nanocomposite (56-NiFe) were tested as antimicrobials against two Gram-positive (S. aureus and B. cereus) and two Gram-negative (E. coli and $P$. aeruginosa) bacteria by the agar-well diffusion method [93]. The results obtained show that the antibacterial activities of the compounds $\mathbf{5 6}$ and 56-NiFe were stronger than that of pure chitosan. The authors postulated that the compounds show weak antibacterial activity against $P$. aeruginosa, medium activity against $B$. cereus and good activity against S. aureus and E. coli. However, the MIC and/or IZD values are not given. 
Table 4. Structure and antibacterial activity of nanoparticles of SBs and CBSs.

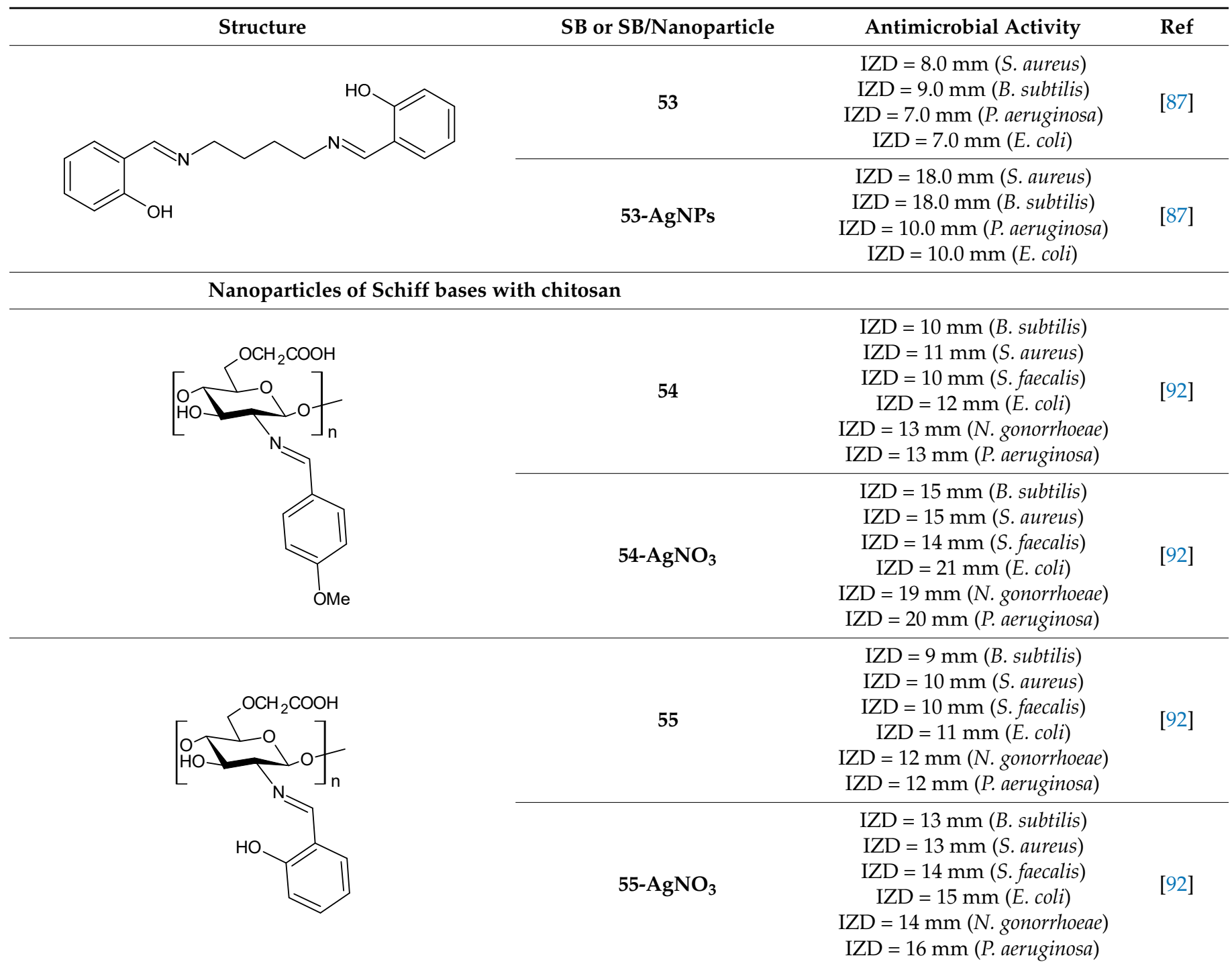

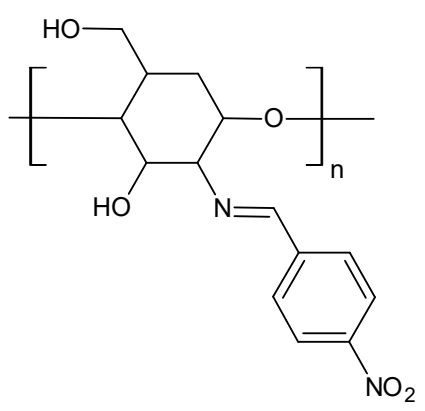

MIC and/or IZD not given.

Only photos are shown

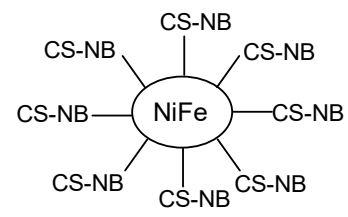

MIC and/or IZD not given.

Only photos are shown

\section{Summary}

SBs are inexpensive compounds and easy to synthesize. They display structural and electronic features that enable their application in a large number of research fields, such 
as analytical, inorganic and organic chemistry. Moreover, their antibacterial, antifungal, anticancer, urease inhibitor and antioxidant effects have been widely reported. Additionally, SBs have shown antiglycation activities, anti-inflammatory, antitumor, antiviral, antipyretic and anti-HIV-1 abilities. Nowadays, the need for more effective antibacterial and antifungal therapies is pressing due to the high mortality rates that are associated with bacterial and fungal diseases as well as the growing number of multidrug-resistant strains. This review summarizes the antimicrobial effects of SBs as described in the recent literature and highlights the importance of CSBs. Chitosan is a product of the deacetylation of chitin, which is widely found in nature. It has proved antibacterial activity, good biodegradation, outstanding biocompatibility, is non-toxic and has excellent chemical and physical properties. As a result, chitosan and its derivatives have been widely tested in the antimicrobial field, showing antibacterial activity against Gram-positive and Gram-negative bacteria as well as antifungal potential. Interestingly, chitosan nanoparticles exhibit antibacterial activity. The most recent studies on CBSs and their nanoparticles as antibacterials have been herein summarized. It is worth mentioning that antibacterial and antitumor activities are generally higher when organic compounds, including SBs, are complexed with metals. Hence, the antimicrobial action of SBs reviewed herein may be taken into account to favor the development of novel metal complexes with improved antimicrobial capacities. Finally, the antibacterial activity of SBs, along with their known anticorrosive potential, might also represent great potential for their future application in several types of surgeries.

Author Contributions: Conceptualization, R.L. and M.S.S.; writing-original draft preparation, J.C.; writing-review and editing D.I. and A.C.; data curation, F.C.; supervision, M.S.S. All authors have read and agreed to the published version of the manuscript.

Funding: This research received no external funding.

Institutional Review Board Statement: Not applicable.

Informed Consent Statement: Not applicable.

Data Availability Statement: Not applicable.

Acknowledgments: We would like to thank the special award, namely "Department of Excellence 2018-2022" (Italian Law 232/2016) at the Department of Pharmacy, Health and Nutritional Sciences of the University of Calabria (Italy) and the "Sistema Integrato di Laboratori per L'Ambiente-(SILA) PONa3_00341".

Conflicts of Interest: The authors declare no conflict of interest.
Abbreviations
A. baumanni Acinetobacter baumanni
ADMET Absorption, distribution, metabolism, excretion and toxicity
A. niger Aspergillus niger
B. cereus Bacillus cereus
B. cinerea Botrytis cinerea
B. subtilis Bacillus subtilis
C. albicanss Candida albicans
C. auris Candida auris
C. glabrata Candida glabrata
CBSs Chitosan-based Schiff bases
ClfA Clumping factor A
CrtM Dehydrosqualene synthase
DFT Density functional theory
DHFR Dihydrofolate reductase
E. coli Escherichia coli
E. faecalis Enterococcus faecalis
FDA Food and Drug Administration 


$\begin{array}{ll}\text { F. graminearum } & \text { Fusarium graminearum } \\ \text { F. oxysporum } & \text { Fusarium oxysporum } \\ \text { IC } 50 & \text { Concentration which kills or inhibits cell viability by 50\% } \\ \text { II } & \text { Inhibitory Index } \\ \text { IZD } & \text { Inhibition zone diameter } \\ \text { K. pneumoniae } & \text { Klebsiella pneumoniae } \\ \text { MEPS } & \text { Molecular electrostatic potential surface } \\ \text { M. luteus } & \text { Micrococcus luteus } \\ \text { MTCC } & \text { Microbial Type Culture Collection } \\ \text { N. gonorrhoeae } & \text { Neisseria gonorrhoeae } \\ \text { P. acnes } & \text { Propionic bacteria acnes } \\ \text { P. aeruginosa } & \text { Pseudomonas aeruginosa } \\ \text { P. asparagi } & \text { Phomopsis asparagi } \\ \text { P. syringae } & \text { Pseudomonas syringae } \\ \text { PEG } & \text { Polyethylene glycol } \\ \text { QSAR } & \text { Quantitative structure activity relationship } \\ \text { SBs } & \text { Schiff bases } \\ \text { S. aureus } & \text { Staphylococcus aureus } \\ \text { S. epidermidis } & \text { Staphylococcus epidermidis } \\ \text { S. faecalis } & \text { Streptococcus faecalis } \\ \text { UPPS } & \text { Undecaprenyl diphosphate synthase }\end{array}$

\section{References}

1. Wang, X.; Ding, G.; Duan, Y.; Zhu, Y.; Zhu, G.; Wang, M.; Li, X.; Zhang, Y.; Qin, X.; Hung, C.H. A novel triphenylamine-based bis-Schiff bases fluorophores with AIE-Activity as the hydrazine fluorescence turn-off probes and cell imaging in live cells. Talanta 2020, 217, 121029. [CrossRef] [PubMed]

2. $\quad$ Berrones-Reyes, J.C.; Muñoz-Flores, B.M.; Cantón-Diáz, A.M.; Treto-Suárez, M.A.; Páez-Hernández, D.; Schott, E.; Zarate, X.; Jiménez-Pérez, V.M. Quantum chemical elucidation of the turn-on luminescence mechanism in two new Schiff bases as selective chemosensors of $\mathrm{Zn}^{2+}$ : Synthesis, theory and bioimaging applications. RSC Adv. 2019, 9, 30778-30789. [CrossRef]

3. Matsumoto, Y.; Sawamura, J.; Murata, Y.; Nishikata, T.; Yazaki, R.; Ohshima, T. Amino acid schiff base bearing benzophenone imine as a platform for highly congested unnatural $\alpha$-amino acid synthesis. J. Am. Chem. Soc. 2020, 142, 8498-8505. [PubMed]

4. Satpati, S.; Saha, S.K.; Suhasaria, A.; Banerjee, P.; Sukul, D. Adsorption and anti-corrosion characteristics of vanillin Schiff bases on mild steel in $1 \mathrm{M} \mathrm{HCl}$ : Experimental and theoretical study. RSC Adv. 2020, 10, 9258-9273. [CrossRef]

5. Ma, L.; Li, W.; Zhu, S.; Wang, L.; Guan, S. Corrosion inhibition of Schiff bases for Mg-Zn-Y-Nd alloy in normal saline: Experimental and theoretical investigations. Corros. Sci. 2021, 184, 109268. [CrossRef]

6. Madani, A.; Sibous, L.; Hellal, A.; Kaabi, I.; Bentouhami, E. Synthesis, density functional theory study, molecular dynamics simulation and anti-corrosion performance of two benzidine Schiff bases. J. Mol. Struct. 2021, 1235, 130224. [CrossRef]

7. Kontham, V.; Ansari, K.R.; Padmaja, K.V. Tribological properties of 10-undecenoic acid-derived schiff base lubricant additives. Arab. J. Sci. Eng. 2021, 46, 5593-5603. [CrossRef]

8. Kontham, V.; Ansari, K.R.; Padmaja, K.V.; Madhu, D. Synthesis and evaluation of stearic acid based heterocyclic Schiff bases as biolubricant additives in epoxy karanja fatty acid 2-ethyl hexyl esters base oil. Industr. Crops Prod. 2021, 159, 113061. [CrossRef]

9. Murmu, M.; Sengupta, S.; Pal, R.; Mandal, S.; Murmu, N.C.; Banerjee, P. Efficient tribological properties of azomethinefunctionalized chitosan as a bio-lubricant additive in paraffin oil: Experimental and theoretical analysis. RSC Adv. 2020, 10, 33401-33416. [CrossRef]

10. Kumar, B.; Kuntail, J.; Verma, D.K.; Rastogi, R.B.; Sinha, I. Mechanism of triboactivity of Schiff bases: Experimental and molecular dynamics simulations studies. J. Mol. Liq. 2019, 289, 111171. [CrossRef]

11. Maity, D. Recent studies on applications of Schiff bases and their complexes in atmospheric carbon dioxide capture. Russ. J. Gen. Chem. 2020, 90, 2473-2483. [CrossRef]

12. Xing, H.; Yaylayan, V. Mechanochemical generation of Schiff bases and Amadori products and utilization of diagnostic MS/MS fragmentation patterns in negative ionization mode for their analysis. Carbohydr. Res. 2020, 495, 108091. [CrossRef] [PubMed]

13. Alamro, F.S.; Gomha, S.M.; Shaban, M.; Altowyan, A.S.; Abolibda, T.Z.; Ahmed, H.A. Optical investigations and photoactive solar energy applications of new synthesized Schiff base liquid crystal derivatives. Sci. Rep. 2021, 11, 1-11.

14. Gomha, S.M.; Ahmed, H.A.; Shaban, M.; Abolibda, T.Z.; Khushaim, M.S.; Alharbi, K.A. Synthesis, optical characterizations and solar energy applications of new Schiff base materials. Materials 2021, 14, 3718. [CrossRef] [PubMed]

15. Jiang, L.; Tian, Y.; Cheng, J.; Zhang, J. A biomass-based Schiff base vitrimer with both excellent performance and multiple degradability. Pol. Chem. 2021, 12, 6527-6537. [CrossRef]

16. Oiye, É.N.; Ribeiro, M.F.M.; Katayama, J.M.T.; Tadini, M.C.; Balbino, M.A.; Eleotério, I.C.; Magalhães, J.; Castro, A.S.; Silva, R.S.M.; da Cruz Júnior, J.W.; et al. Electrochemical sensors containing schiff bases and their transition metal complexes to detect analytes of forensic, pharmaceutical and environmental interest. A review. Crit. Rev. Anal. Chem. 2019, 49, 488-509. [CrossRef] [PubMed] 
17. Mishra, N.; Yadav, R.; Kumar, K.; Pandey, H.; Pandey, R. Conventional vs. Microwave assisted $\mathrm{SiO}_{2} / \mathrm{P}_{2} \mathrm{O}_{5}$ catalyzed synthesis of Schiff bases. J. Phys. Conf. Ser. 2020, 1504, 012002. [CrossRef]

18. Wady, A.F.; Hussein, M.B.; Mohammed, M.M. Synthesis, characterization of Schiff bases derived from salicylaldehyde with some amino acids by a new developed method. Sch. Int. J. Chem. Mater. Sci. 2021, 4, 46-53.

19. Sk, I.; Khan, M.A.; Haque, A.; Ghosh, S.; Roy, D.; Homechuadhuri, S.; Alam, M.A. Synthesis of gold and silver nanoparticles using Malva verticillata leaves extract: Study of gold nanoparticles catalysed reduction of nitro-Schiff bases and antibacterial activities of silver nanoparticles. Curr. Res. Green Sustain. Chem. 2020, 3, 100006. [CrossRef]

20. Munawar, K.S.; Haroon, S.M.; Hussain, S.A.; Raza, H. Schiff bases: Multipurpose pharmacophores with extensive biological applications. J. Basic Appl. Sci. 2018, 14, 217-229. [CrossRef]

21. Iacopetta, D.; Lappano, R.; Mariconda, A.; Ceramella, J.; Sinicropi, M.S.; Saturnino, C.; Talia, M.; Cirillo, F.; Martinelli, F.; Puoci, F. Newly synthesized imino-derivatives analogues of resveratrol exert inhibitory effects in breast tumor cells. Int. J. Mol. Sci. 2020, 21, 7797. [CrossRef] [PubMed]

22. Rana, K.; Pandurangan, A.; Singh, N.; Tiwari, A.K. A systemic review of Schiff bases as an analgesic, anti-inflammatory. Int. J. Curr. Pharm. Res. 2012, 4, 5-11.

23. Hameed, A.; Al-Rashida, M.; Uroos, M.; Abid Ali, S.; Khan, K.M. Schiff bases in medicinal chemistry: A patent review (2010-2015) Exp. Opin. Ther. Pat. 2017, 27, 63-79. [CrossRef] [PubMed]

24. Da Silva, C.M.; da Silva, D.L.; Modolo, L.V.; Alves, R.B.; de Resende, M.A.; Martins, C.V.B.; de Fátima, Â. Schiff bases: A short review of their antimicrobial activities. J. Adv. Res. 2011, 2, 1-8.

25. Iacopetta, D.; Ceramella, J.; Catalano, A.; Saturnino, C.; Bonomo, M.G.; Franchini, C.; Sinicropi, M.S. Schiff bases: Interesting scaffolds with promising antitumoral properties. Appl. Sci. 2021, 11, 1877. [CrossRef]

26. Smolyaninov, I.V.; Burmistrova, D.A.; Arsenyev, M.V.; Almyasheva, N.R.; Ivanova, E.S.; Smolyaninova, S.A.; Pashchenko, K.P.; Poddel'sky, A.I.; Berberova, N.T. Catechol-and phenol-containing thio-Schiff bases: Synthesis, electrochemical properties and biological evaluation. ChemistrySelect 2021, 6, 10609-10618. [CrossRef]

27. Howsaui, H.B.; Basaleh, A.S.; Abdellattif, M.H.; Hassan, W.M.; Hussien, M.A. Synthesis, structural investigations, molecular docking, and anticancer activity of some novel Schiff bases and their uranyl complexes. Biomolecules 2021, 11, 1138. [CrossRef]

28. Kaczmarek, M.T.; Zabiszak, M.; Nowak, M.; Jastrzab, R. Lanthanides: Schiff base complexes, applications in cancer diagnosis, therapy, and antibacterial activity. Coord. Chem. Rev. 2018, 370, 42-54. [CrossRef]

29. Catalano, A.; Sinicropi, M.S.; Iacopetta, D.; Ceramella, J.; Mariconda, A.; Rosano, C.; Scali, E.; Saturnino, C.; Longo, P. A review on the advancements in the field of metal complexes with Schiff bases as antiproliferative agents. Appl. Sci. 2021, 11, 6027. [CrossRef]

30. Catalano, A.; Iacopetta, D.; Ceramella, J.; Scumaci, D.; Giuzio, F.; Saturnino, C.; Aquaro, S.; Rosano, C.; Sinicropi, M.S. Multidrug resistance (MDR): A widespread phenomenon in pharmacological therapies. Molecules, 2021; submitted.

31. Iacopetta, D.; Catalano, A.; Ceramella, J.; Saturnino, C.; Salvagno, L.; Ielo, I.; Drommi, D.; Scali, E.; Plutino, M.R.; Rosace, G.; et al. The different facets of triclocarban: A review. Molecules 2021, 26, 2811. [CrossRef]

32. Catalano, A.; Iacopetta, D.; Pellegrino, M.; Aquaro, S.; Franchini, C.; Sinicropi, M.S. Diarylureas: Repositioning from antitumor to antimicrobials or multi-target agents against new pandemics. Antibiotics 2021, 10, 92. [CrossRef] [PubMed]

33. Pervaiz, M.; Sadiq, S.; Sadiq, A.; Younas, U.; Ashraf, A.; Saeed, Z.; Zuber, M.; Adnan, A. Azo-Schiff base derivatives of transition metal complexes as antimicrobial agents. Coord. Chem. Rev. 2021, 447, 214128. [CrossRef]

34. Mohan, C.; Kumar, V.; Kumari, N.; Kumari, S.; Yadav, J.; Gandass, T.; Yadav, S. Synthesis, characterization and antibacterial activity of semicarbazide based Schiff bases and their $\mathrm{Pb}(\mathrm{II}), \mathrm{Zr}(\mathrm{IV})$ and U(VI) complexes. Adv. J. Chem. Sect. B 2020, 2, 187-196.

35. Khalid, S.; Sumrra, S.H.; Chohan, Z.H. Isatin endowed metal chelates as antibacterial and antifungal agents. Sains Malays. 2020, 49, 1891-1904. [CrossRef]

36. Xua, Y.; Shia, Y.; Leia, F.; Dai, L. A novel and green cellulose-based Schiff base-Cu (II) complex and its excellent antibacterial activity. Carbohydr. Polym. 2020, 230, 115671. [CrossRef]

37. Pour, S.R.; Abdolmaleki, A.; Dinari, M. Immobilization of new macrocyclic Schiff base copper complex on graphene oxide nanosheets and its catalytic activity for olefins epoxidation. J. Mater. Sci. 2019, 54, 2885-2896. [CrossRef]

38. Fernández-G. J.M.; del Rio-Portilla, F.; Quiroz-García, B.; Toscano, R.A.; Salcedo, R. The structures of some ortho-hydroxy Schiff base ligands. J. Mol. Struct. 2001, 561, 197-207. [CrossRef]

39. Antony, R.; Arun, T.; Manickam, S.T.D. A review on applications of chitosan-based Schiff bases. Int. J. Biol. Macromol. 2019, 129, 615-633. [CrossRef]

40. Imam, S.S.; Alshehri, S.; Ghoneim, M.M.; Zafar, A.; Alsaidan, O.A.; Alruwaili, N.K.; Gilani, S.J.; Rizwanullah, M. Recent advancement in chitosan-based nanoparticles for improved oral bioavailability and bioactivity of phytochemicals: Challenges and perspectives. Polymers 2021, 13, 4036. [CrossRef]

41. Zhang, Y.; Zhao, M.; Cheng, Q.; Wang, C.; Li, H.; Han, X.; Fan, Z.; Su, G.; Pan, D.; Li, Z. Research progress of adsorption and removal of heavy metals by chitosan and its derivatives: A review. Chemosphere 2021, 279, 130927. [CrossRef]

42. Li, J.; Zhuang, S. Antibacterial activity of chitosan and its derivatives and their interaction mechanism with bacteria: Current state and perspectives. Eur. Polym. J. 2020, 138, 109984. [CrossRef]

43. Confederat, L.G.; Tuchilus, C.G.; Dragan, M.; Sha'at, M.; Dragostin, O.M. Preparation and antimicrobial activity of chitosan and its derivatives: A concise review. Molecules 2021, 26, 3694. [CrossRef] [PubMed] 
44. Amourizi, F.; Dashtian, K.; Ghaedi, M.; Hosseinzadeh, B. An asymmetric Schiff base-functionalized gold nanoparticle-based colorimetric sensor for $\mathrm{Hg}^{2+}$ ion determination: Experimental and DFT studies. Anal. Methods. 2021, 13, 2603-2611. [CrossRef] [PubMed]

45. Whitty-Léveillé, L.; Tremblay-Cantin, J.C.; Picard-Lafond, A.; Boudreau, D.; Reynier, N.; Larivière, D. Core-shell nanoparticles bearing Schiff base ligand for the selective extraction of uranium from REE leach liquors. Hydrometal. 2021, 208, 105780. [CrossRef]

46. Rosato, A.; Catalano, A.; Carocci, A.; Carrieri, A.; Carone, A.; Caggiano, G.; Franchini, C.; Corbo, F.; Montagna, M.T. In vitro interactions between anidulafungin and nonsteroidal anti-inflammatory drugs on biofilms of Candida spp. Bioorg. Med. Chem. 2016, 24, 1002-1005. [CrossRef]

47. Hassan, A.S.; Askar, A.A.; Nossier, E.S.; Naglah, A.M.; Moustafa, G.O.; Al-Omar, M.A. Antibacterial evaluation, in silico characters and molecular docking of Schiff bases derived from 5-aminopyrazoles. Molecules 2019, 24, 3130. [CrossRef]

48. Pozzi, C.; Ferrari, S.; Cortesi, D.; Luciani, R.; Stroud, R.M.; Catalano, A.; Costi, M.P.; Mangani, S. The structure of Enterococcus faecalis thymidylate synthase provides clues about folate bacterial metabolism. Acta Cryst. D 2012, 68, 1232-1241. [CrossRef]

49. Gümüş, A.; Okumuş, V.; Gümüş, S. Synthesis, biological evaluation of antioxidant-antibacterial activities and computational studies of novel anthracene-and pyrene-based Schiff base derivatives. Turk. J. Chem. 2020, 44, 1200-1215. [CrossRef]

50. Erturk, A.G. Synthesis, structural identifications of bioactive two novel Schiff bases. J. Mol. Struct. 2020, 1202, 27299. [CrossRef]

51. Mishra, N.; Kumar, K.; Pandey, H.; Anand, S.R.; Yadav, R.; Srivastava, S.P.; Pandey, R. Synthesis, characterization, optical and anti-bacterial properties of benzothiazole Schiff bases and their lanthanide(III)complexes. J. Saudi Chem. Soc. 2020, 24, 925-933. [CrossRef]

52. Yusuf, T.L.; Oladipo, S.D.; Olagboye, S.A.; Zamisa, S.J.; Tolufashe, G.F. Solvent-free synthesis of nitrobenzyl Schiff bases: Characterization, antibacterial studies, density functional theory and molecular docking studies. J. Mol. Struct. 2020, $1222,128857$. [CrossRef]

53. Chemchem, M.; Menacer, R.; Merabet, N.; Bouridane, H.; Yahiaoui, S.; Moussaoui, S.; Belkhiri, L. Green synthesis, antibacterial evaluation and QSAR analysis of some isatin Schiff bases. J. Mol. Struct. 2020, 1208, 127853. [CrossRef]

54. Warad, I.; Ali, O.; Al Ali, A.; Jaradat, N.A.; Hussein, F.; Abdallah, L.; Al-Zaqri, N.; Alsalme, A.; Alharthi, F.A. Synthesis and spectral Identification of three Schiff bases with a 2-(piperazin-1-yl)- $N$-(thiophen-2-yl methylene) ethanamine moiety acting as novel pancreatic lipase inhibitors: Thermal, DFT, antioxidant, antibacterial, and molecular docking investigations. Molecules 2020, 25, 2253. [CrossRef] [PubMed]

55. Bayeh, Y.; Mohammed, F.; Gebrezgiabher, M.; Elemo, F.; Getachew, M.; Thomas, M. Synthesis, characterization and antibacterial activities of polydentate Schiff bases, based on salicylaldehyde. Adv. Biol. Chem. 2020, 10, 127-139. [CrossRef]

56. Anwar, S.; Khan, M.A.; Ahmed, I.; Pervaiz, I.; Shah, H.S. Development of Schiff bases from amikacin: Synthesis, antibacterial, anti-urease activities and molecular docking studies. Lett. Drug Des. Discov. 2020, 17, 1579-1588. [CrossRef]

57. Salihović, M.; Pazalja, M.; Halilović, S.Š.; Veljović, E.; Mahmutović-Dizdarević, I.; Roca, S.; Novaković, I.; Trifunović, S. Synthesis, characterization, antimicrobial activity and DFT study of some novel Schiff bases. J. Mol Struct. 2021, 1241, 130670. [CrossRef]

58. Srinivasan, V.; Khamrang, T.; Ponraj, C.; Saravanan, D.; Yamini, R.; Bera, S.; Jhonsi, M.A. Pyrene based Schiff bases: Synthesis, crystal structure, antibacterial and BSA binding studies. J. Mol. Struct. 2021, 1225, 129153. [CrossRef]

59. Sumrra, S.H.; Zafar, W.; Asghar, M.L.; Mushtaq, F.; Raza, M.A.; Nazar, M.F.; Nadeem, M.A.; Imran, M.; Mumtaz, S. Computational investigation of molecular structures, spectroscopic properties, cholinesterase inhibition and antibacterial activities of triazole Schiff bases endowed metal chelates. J. Mol. Struct. 2021, 1238, 130382. [CrossRef]

60. Ragi, K.; Kakkassery, J.T.; Raphael, V.P.; Johnson, R. In vitro antibacterial and in silico docking studies of two Schiff bases on Staphylococcus aureus and its target proteins. Fut. J. Pharm. Sci. 2021, 7, 1-9.

61. Singhal, S.; Khanna, P.; Khanna, L. Synthesis, comparative in vitro antibacterial, antioxidant \& UV fluorescence studies of bis indole Schiff bases and molecular docking with ct-DNA \& SARS-CoV-2 Mpro. Luminescence 2021, 36, 1531-1543.

62. Aragón-Muriel, A.; Liscano, Y.; Upegui, Y.; Robledo, S.M.; Ramírez-Apan, M.T.; Morales-Morales, D.; Oñate-Garzón, J.; PoloCerón, D. In vitro evaluation of the potential pharmacological activity and molecular targets of new benzimidazole-based schiff base metal complexes. Antibiotics 2021, 10, 728. [CrossRef] [PubMed]

63. Carocci, A.; Catalano, A.; Bruno, C.; Lentini, G.; Franchini, C.; De Bellis, M.; De Luca, A.; Conte Camerino, D. Synthesis and in vitro sodium channel blocking activity evaluation of novel homochiral mexiletine analogs. Chirality 2010, 22, $299-307$. [CrossRef] [PubMed]

64. Magalhães, T.F.F.; da Silva, C.M.; Dos Santos, L.B.F.; Santos, D.A.; Silva, L.M.; Fuchs, B.B.; Mylonakis, E.; Martins, C.V.B.; de Resende-Stoianoff, M.A.; de Fátima, Â. Cinnamyl Schiff bases: Synthesis, cytotoxic effects and antifungal activity of clinical interest. Lett. Appl. Microbiol. 2020, 71, 490-497. [CrossRef] [PubMed]

65. Chen, Y.; Mi, Y.; Li, Q.; Dong, F.; Guo, Z. Synthesis of Schiff bases modified inulin derivatives for potential antifungal and antioxidant applications. Int. J. Biol. Macromol. 2020, 143, 714-723. [CrossRef]

66. Guo, Z.; Li, Q.; Wang, G.; Dong, F.; Zhou, H.; Zhang, J. Synthesis, characterization, and antifungal activity of novel inulin derivatives with chlorinated benzene. Carbohydr. Polym. 2014, 99, 469-473. [CrossRef]

67. Hamad, A.; Chen, Y.; Khan, M.A.; Jamshidi, S.; Saeed, N.; Clifford, M.; Hind, C.; Sutton, J.M.; Rahman, K.M. Schiff bases of sulphonamides as a new class of antifungal agent against multidrug-resistant Candida auris. Microbiol. Open 2021, 10, e1218. [CrossRef]

68. Bhattacharya, S.; Sae-Tia, S.; Fries, B.C. Candidiasis and mechanisms of antifungal resistance. Antibiotics 2020, 9, 312. [CrossRef] 
69. Chowdhary, A.; Tarai, B.; Singh, A.; Sharma, A. Multidrug-resistant Candida auris infections in critically Ill coronavirus disease patients, India, April-July 2020. Emerg. Infect. Dis. 2020, 26, 2694. [CrossRef]

70. Bhagwatrao Biradar, S.; Vithal Narte, D.; Pradip Kale, R.; Momin, K.I.; Sudewad, M.S.; Tayade, K.C.; Palke, D.G. Synthesis, spectral and biological studies of DHA Schiff bases. J. Appl. Organometal. Chem. 2021, 1, 41-47.

71. Wang, W.; Meng, Q.; Li, Q.; Liu, J.; Zhou, M.; Jin, Z.; Zhao, K. Chitosan derivatives and their application in biomedicine. Int. J. Mol. Sci. 2020, 21, 487. [CrossRef]

72. Hamed, A.A.; Abdelhamid, I.A.; Saad, G.R.; Elkady, N.A.; Elsabee, M.Z. Synthesis, characterization and antimicrobial activity of a novel chitosan Schiff bases based on heterocyclic moieties. Int. J. Biol. Macromol. 2020, 153, 492-501. [CrossRef] [PubMed]

73. Elhag, M.; Abdelwahab, H.E.; Mostafa, M.A.; Nasr, A.Z.; El Sadek, M.M. Synthesis and characterization of chitosanpyrazoloquinoxaline Schiff bases for $\mathrm{Cr}(\mathrm{VI})$ removal from wastewater. Int. J. Biol. Macromol. 2020, 163, 2180-2188. [PubMed]

74. Genchi, G.; Lauria, G.; Catalano, A.; Carocci, A.; Sinicropi, M.S. The double face of metals: The intriguing case of chromium. Appl. Sci. 2021, 11, 638. [CrossRef]

75. Barbosa, H.F.G.; Attjioui, M.; Ferreira, A.P.G.; Dockal, E.R.; El Gueddari, N.E.; Moerschbacher, B.M.; Cavalheiro, É.T.G. Synthesis, characterization and biological activities of biopolymeric Schiff bases prepared with chitosan and salicylaldehydes and their Pd(II) and Pt(II) complexes. Molecules 2017, 22, 1987. [CrossRef] [PubMed]

76. Wei, L.; Tan, W.; Wang, G.; Li, Q.; Dong, F.; Guo, Z. The antioxidant and antifungal activity of chitosan derivatives bearing Schiff bases and quaternary ammonium salts. Carbohydr. Pol. 2019, 226, 115256. [CrossRef]

77. Hassan, M.A.; Omer, A.M.; Abbas, E.; Baset, W.M.; Tamer, T.M. Preparation, physicochemical characterization and antimicrobial activities of novel two phenolic chitosan Schiff base derivatives. Sci. Rep. 2018, 8, 1-14. [CrossRef]

78. Ali, S.S.; Kenawy, E.R.; Sonbol, F.I.; Sun, J.; Al-Etewy, M.; Ali, A.; Huizi, L.; El-Zawawy, A.N. Pharmaceutical potential of a novel chitosan derivative Schiff base with special reference to antibacterial, anti-biofilm, antioxidant, anti-inflammatory, hemocompatibility and cytotoxic activities. Pharm. Res. 2018, 36, 5. [CrossRef]

79. Wei, L.; Zhang, J.; Tan, W.; Wang, G.; Li, Q.; Dong, F.; Guo, Z. Antifungal activity of double Schiff bases of chitosan derivatives bearing active halogeno-benzenes. Int. J. Biol. Macromol. 2021, 179, 292-298. [CrossRef]

80. Kesharwani, P.; Gorain, B.; Choudhury, H.; Pandey, M.; Low, S.Y.; Tan, S.A.; Ling, E.C.S.; Lim, Y.K.; Chin, C.M.; Lee, P.Y.; et al. Nanotechnology based approaches for anti-diabetic drugs delivery. Diabetes Res. Clin. Pract. 2018, 136, 52-77. [CrossRef]

81. Ceramella, J.; Mariconda, A.; Iacopetta, D.; Saturnino, C.; Barbarossa, A.; Caruso, A.; Rosano, C.; Sinicropi, M.S.; Longo, P. From coins to cancer therapy: Gold, silver and copper complexes targeting human topoisomerases. Bioorg. Med. Chem. Lett. 2020, 30, 126905-126916. [CrossRef]

82. Salleh, A.; Naomi, R.; Utami, N.D.; Mohammad, A.W.; Mahmoudi, E.; Mustafa, N.; Fauzi, M.B. The potential of silver nanoparticles for antiviral and antibacterial applications: A mechanism of action. Nanomaterials 2020, 10, 1566. [CrossRef] [PubMed]

83. Wang, L.; Li, S.; Yin, J.; Yang, J.; Li, Q.; Zheng, W.; Liu, S.; Jiang, X. The density of surface coating can contribute to different antibacterial activities of gold nanoparticles. Nano Lett. 2020, 20, 5036-5042. [CrossRef] [PubMed]

84. Song, J.; Xu, B.; Yao, H.; Lu, X.; Tan, Y.; Wang, B.; Wang, X.; Yang, Z. Schiff-linked PEGylated doxorubicin prodrug forming pH-responsive nanoparticles with high drug loading and effective anticancer therapy. Front. Oncol. 2021, 11, 890. [CrossRef] [PubMed]

85. Rahbar, M.; Morsali, A.; Bozorgmehr, M.R.; Beyramabadi, S.A. Quantum chemical studies of chitosan nanoparticles as effective drug delivery systems for 5-fluorouracil anticancer drug. J. Mol. Liq. 2020, 302, 112495. [CrossRef]

86. Sen, P.; Nyokong, T. Enhanced photodynamic inactivation of Staphylococcus aureus with Schiff base substituted zinc phthalocyanines through conjugation to silver nanoparticles. J. Mol. Struct. 2021, 1232, 130012. [CrossRef]

87. Minhaz, A.; Khan, N.; Jamila, N.; Javed, F.; Imran, M.; Shujah, S.; Khan, S.N.; Atlas, A.; Shah, M.R. Schiff base stabilized silver nanoparticles as potential sensor for $\mathrm{Hg}$ (II)detection, and anticancer and antibacterial agent. Arab. J. Chem. 2020, 13, 8898-8908. [CrossRef]

88. Elmehbad, N.Y.; Mohamed, N.A. Designing, preparation and evaluation of the antimicrobial activity of biomaterials based on chitosan modified with silver nanoparticles. Int. J. Biol. Macromol. 2020, 151, 92-103. [CrossRef]

89. Ahmed, M.E.; Mohamed, H.M.; Mohamed, M.I.; Kandile, N.G. Sustainable antimicrobial modified chitosan and its nanoparticles hydrogels: Synthesis and characterization. Int. J. Biol. Macromol. 2020, 162, 1388-1397. [CrossRef]

90. Montaser, A.S.; Wassel, A.R.; Al-Shaye'a, O.N. Synthesis, characterization and antimicrobial activity of Schiff bases from chitosan and salicylaldehyde/ $\mathrm{TiO}_{2}$ nanocomposite membrane. Int. J. Biol. Macromol. 2019, 124, 802-809. [CrossRef]

91. Boroumand, H.; Badie, F.; Mazaheri, S.; Seyedi, Z.S.; Nahand, J.S.; Nejati, M.; Baghi, H.B.; Abbasi-Kolli, M.; Badehnoosh, B.; Ghandali, M.; et al. Chitosan-based nanoparticles against viral infections. Front. Cell Infect. Microbiol. 2021, 11, 643953. [CrossRef]

92. Abdel-Monem, R.A.; Khalil, A.M.; Darwesh, O.M.; Hashim, A.I.; Rabie, S.T. Antibacterial properties of carboxymethyl chitosan Schiff-base nanocomposites loaded with silver nanoparticles. J. Macromol. Sci. Part A 2020, 57, 145-155. [CrossRef]

93. Cao, Y.; Alamri, S.; Rajhi, A.A.; Anqi, A.E.; Khalaji, A.D. New chitosan Schiff base and its nanocomposite: Removal of methyl green from aqueous solution and its antibacterial activities. Int. J. Biol. Macromol. 2021, 192, 1-6. [CrossRef] [PubMed] 